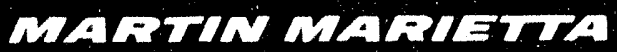

\title{
Resource Conservation and Recovery Act (RCRA) Contingency Plan for Interim Status or Permitted Units at the Oak Ridge Y-12 Plant
}

Health, Safety, Environment, and Accountability Organization

August 1992

Prepared by the

Oak Ridge Y-12 Plant

Oak Ridge, Tennessee 37831

Managed by

MARTIN MARIETTA ENERGY SYSTEMS, INC.

for the

U.S. DEPARTMENT OF ENERGY

under contract DE-AC05-84OR21400

\section{MAMAGED BY}

MARTIN MARIETTA ENERGY SYSTEMS, INC.

FOR THE UNITED STATES

DEPARTMENT OF ENERGY 


\section{DISCLAIMER}

This report was prepared as an account of work sponsored by an agency of the United States Government. Neither the United States Government nor any agency thereof, nor any of their employees, makes any warranty, express or implied, or assumes any legal liability or responsibility for the accuracy, completeness, or usefulness of any information, apparatus, product, or process disclosed, or represents that its use would not infringe privately owned rights. Reference herein to any specific commercial product, process, or service by trade name, trademark, manufacturer, or otherwise, does not necessarily constitute or imply its endorsement, recommendation, or favoring by the United States Government or any agency thereof. The views and opinions of authors expressed herein do not necessarily state or reflect those of the United States Government or any agency thereof. 


\title{
Resource Conservation and Recovery Act (RCRA) Contingency Plan for Interim Status or Permitted Units at the Oak Ridge Y-12 Plant
}

\author{
Health, Safety, Environment, and Accountability Organization \\ August 1992
}

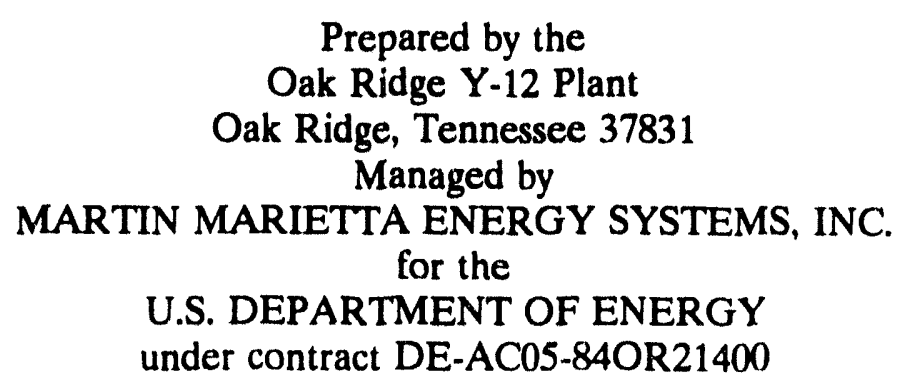

Carm

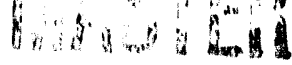




\title{
Y-12 PLANT \\ RESOURCE CONSERVATION AND RECOVERY ACT (RCRA) CONTINGENCY PLAN FOR INTERIM STATUS OR PERMITTED FACILITIES
}

\section{GENERAL FACILITY DESCRIPTION}

The Oak Ridge Y-12 Plant was built for the U. S. Army Corps of Engineers in 1943 as part of the Manhattan Project and was given the original mission to separate the fissionable isotope of uranium (U-235) by the electromagnetic process. After World War II the electromagnetic process was discontinued in favor of the more economical gaseous diffusion process. In recent years, the Y-12 Plant has developed into a more highly sophisticated manufacturing and developmental engineering organization.

The U. S. Department of Energy (DOE) owns and operates the Y.12 Plant. Martin Marietta Energy Systems, Inc., co-operates (under RCRA) and manages the Y-12 Plant. Since 1984 the facility has been managed by Martin Marietta Energy Systems. Inc., under a prime contract with the U.S. Department of Ënergy. The contract is administered by the DOE Field Office, Oak Ridge.

The ${ }^{\prime}-12$ Plant occupies approximately 800 acres in Anderson County, Tennessee, and is located southwest of the City of Oak Ridge. The site employs approximately 8,100 people including employees of the Oak Ridge National Laboratory (ORNL) assigned to the Y-12 Plant. Two surface streams, East Fork Poplar Creek and Bear Creek, border the facility on the south, east, and southwest sides of the Plant. There is access to the Y-12 Plant, that is controlled on Bear Creek Road, on the north side of the facility, indirect access from Scarboro Road on the east side of the facility, and indirect access to the facility on the south side through Bethel Valley Road. A controlled access road from Bethel Valley Road by way of Mt. Vernon Road is located on the southwest side of the site. The mailing address is:

\author{
Y-12 Plant Manager \\ Department of Energy Field Office, Oak Ridge \\ Post Office Box 2009 \\ Oak Ridge, TN 37831
}


The official mission of the Y-12 Plant is to serve as a manufacturing technology center for key processes such that capabilities are maintained for safe. secure. reliable. and survivable nuclear weapons systems and other applications of national importance.

\section{GENERAL INFORMATION}

The Y-12 RCRA Contingency Plan will be reviewed and revised if necessary if the facility RCRA operating permits are revised, the plan is inadequate in an emergency, the procedures herein can be improved, the facility's operations change in a manner that alters the plan, the emergency coordinator changes, or the emergency equipment list changes. Copies of the Y-12 Emergency Management Plan are available at the Plant Shift Superintendent's Office and the Emergency Preparedness Office. This document serves to supplement the Y-12 Emergency Management Plan to be appropriate for all RCRA hazardous waste interim status or permitted treatment, storage, or disposal facilities. The 90-day storage areas at the Y-12 Plant have a separate contingency supplement as required by RCRA and are separate from this supplement.

The facility name. address, ID number. and owner/operator name are provided below:

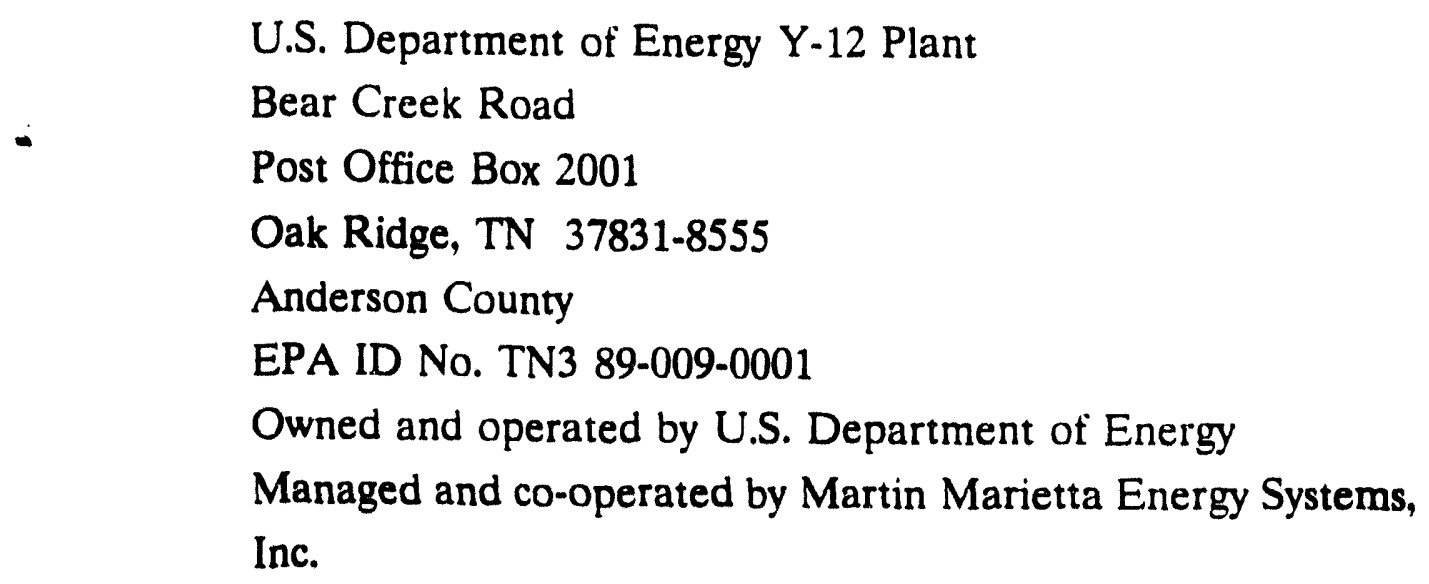

The Y-12 Plant is divided into six primary emergency zones so that the general location of an emergency can be indicated. A seventh is designated for areas adjacent to the main Y-12 Plant area. The overall layout of the Y-12 Plant. the six primary emergency zones. and the location of RCRA facilities are shown in Figure G-1, Y-12 Plant Emergency Zones and Facilities. Figure G-2. Y-12 Plant Emergency Facilities Directory, shows that locations of assembly stations, boundaries, and access controls to the plant. Figure G-3. Y-12 Plant Bear Creek Burial Ground Waste Unit Map, shows the units located at the west end of the plant. 

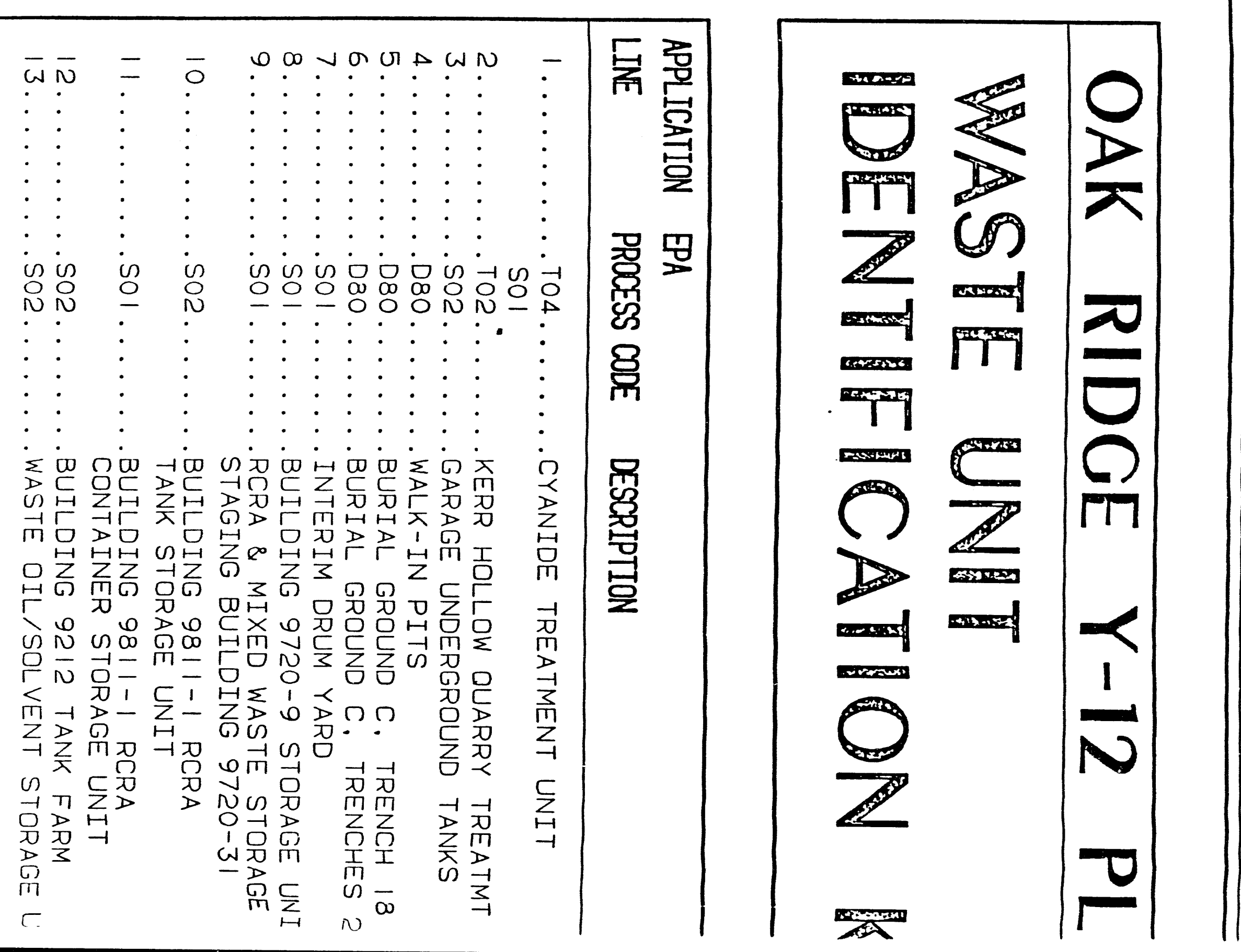


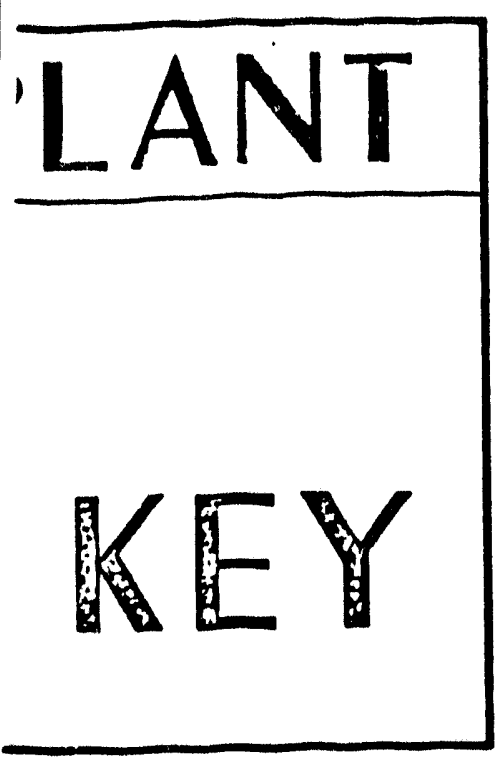

+TMT UNITS

is

$+18$

HES 20-21

EUNIT

रAGE \&

31

$M$

AGE UNIT

TOR. UNIT

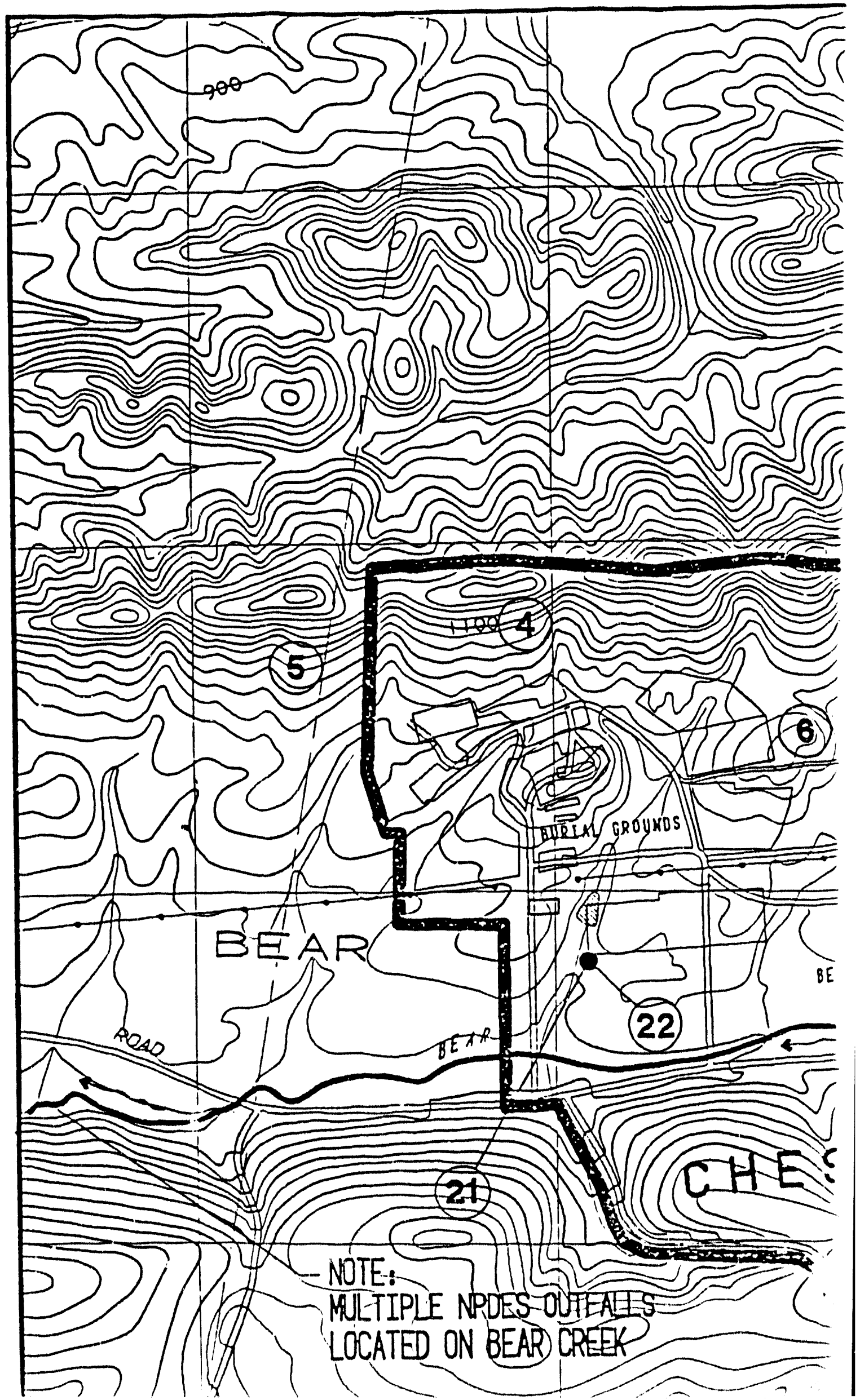




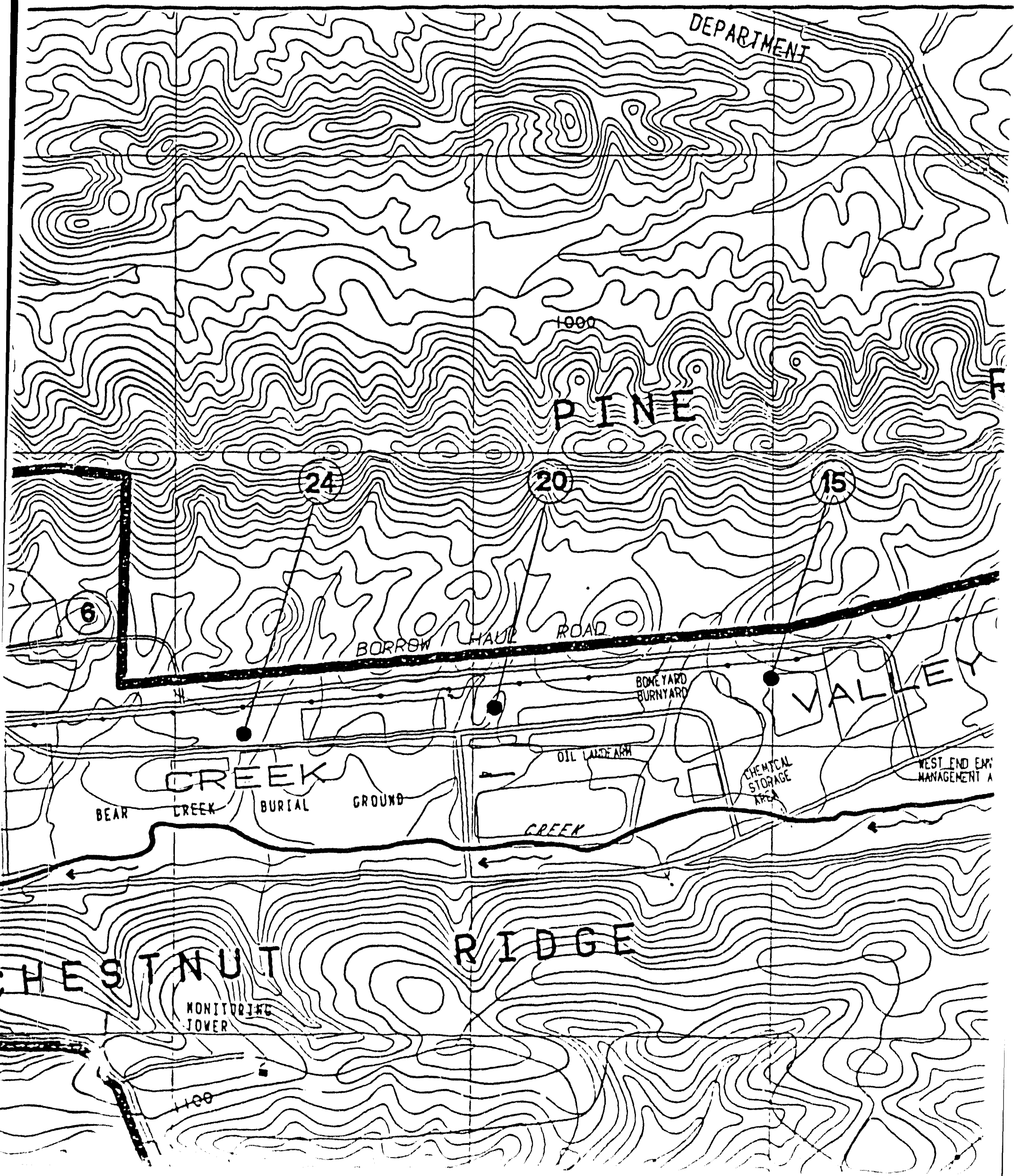




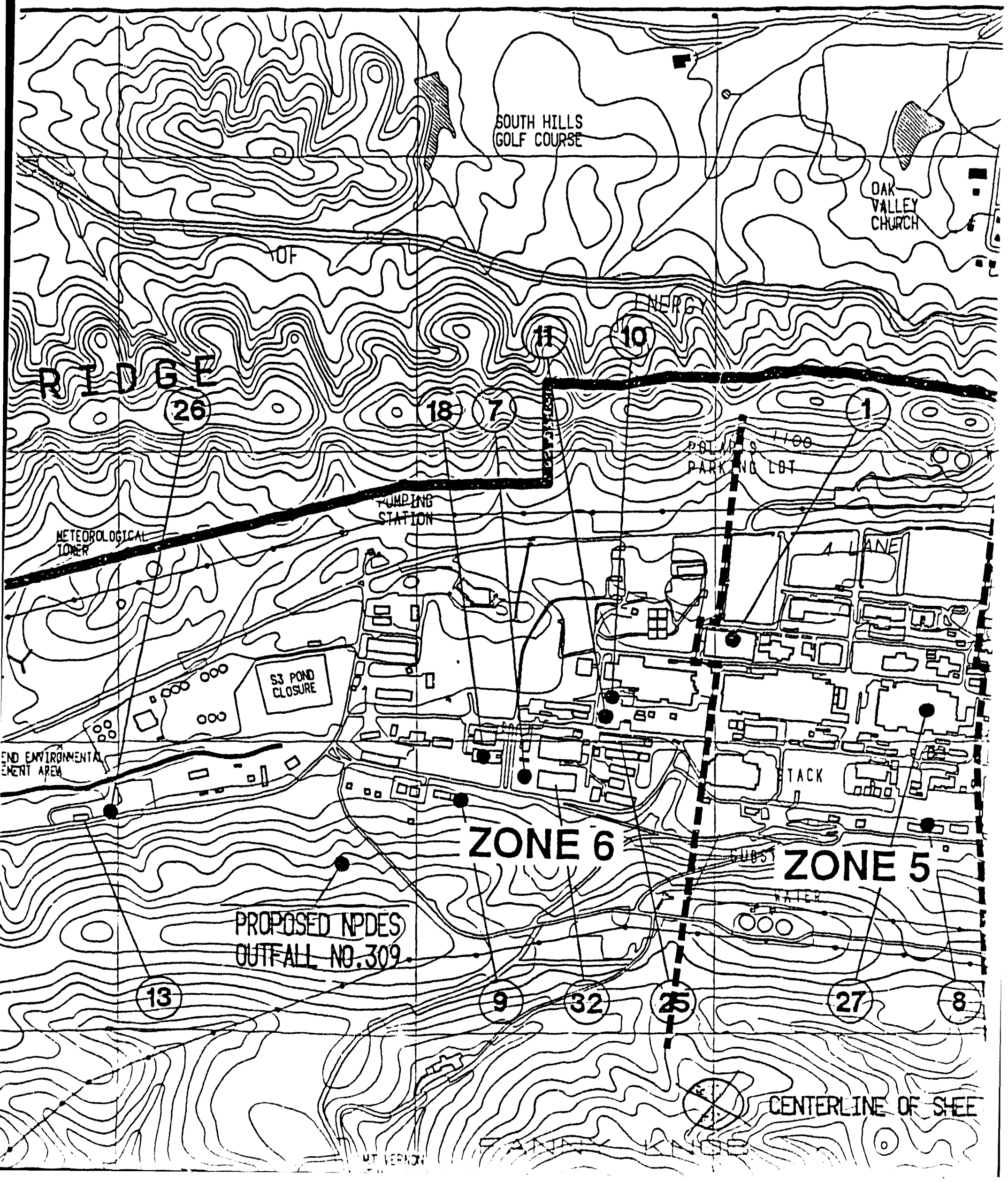




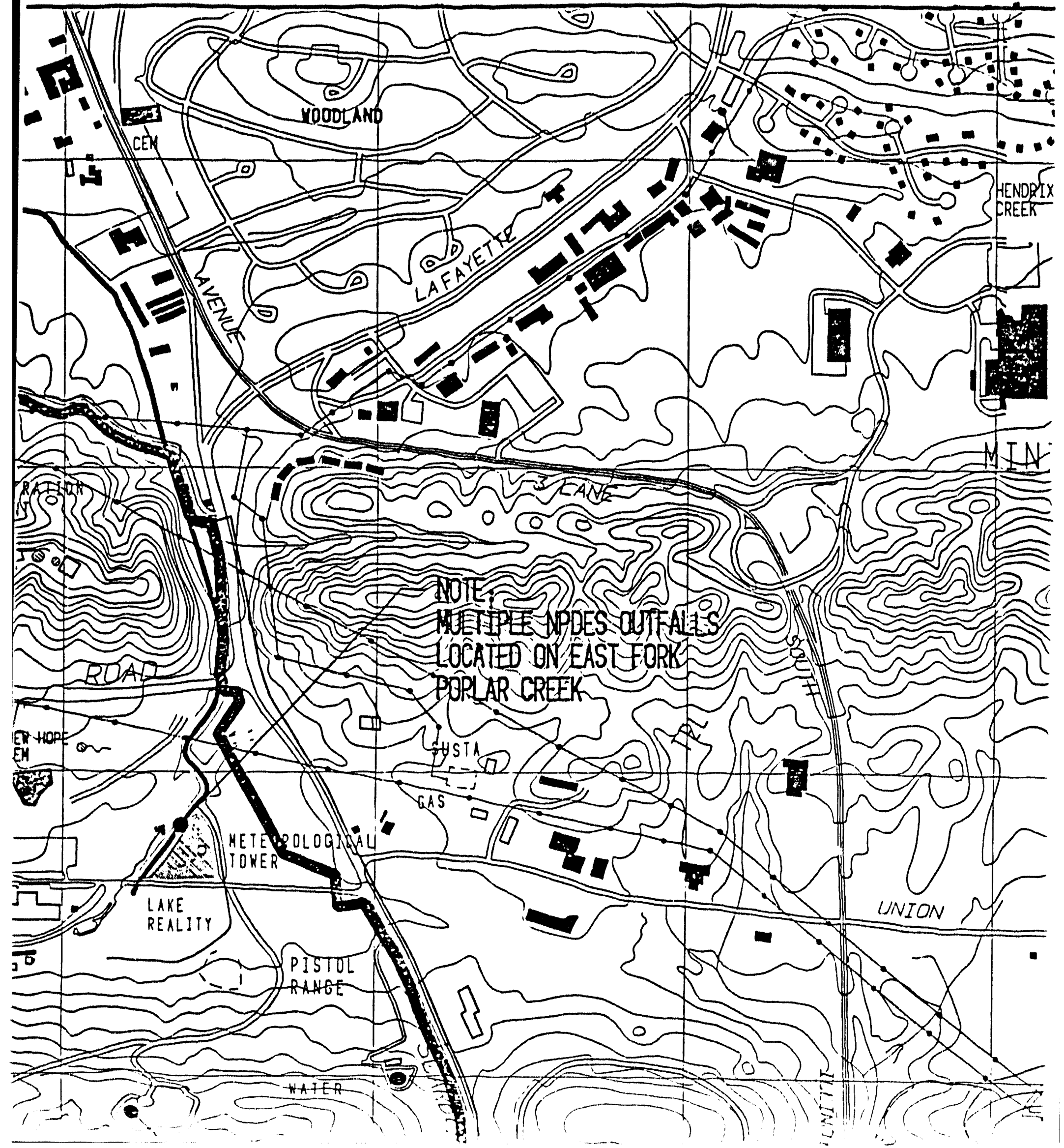




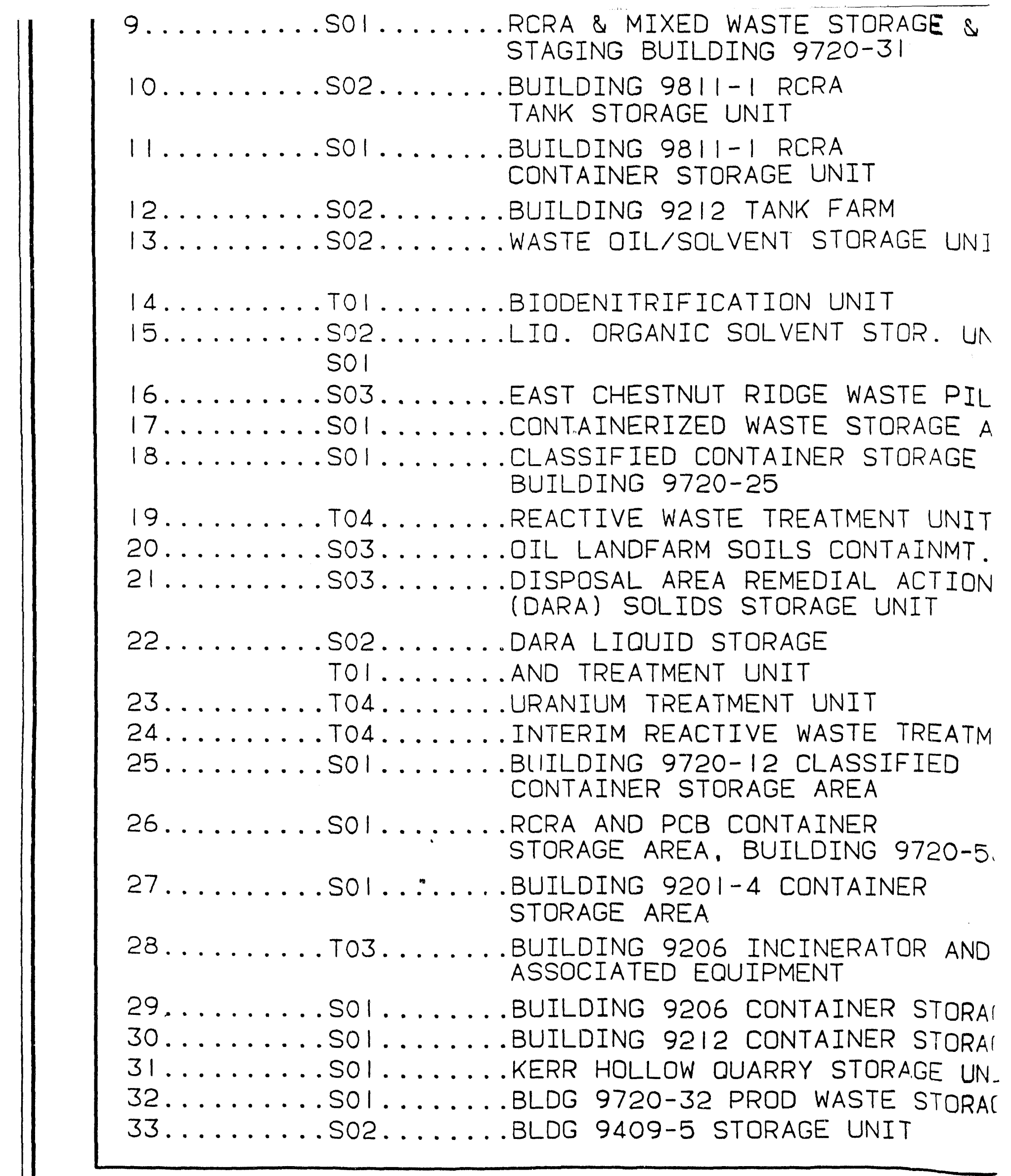

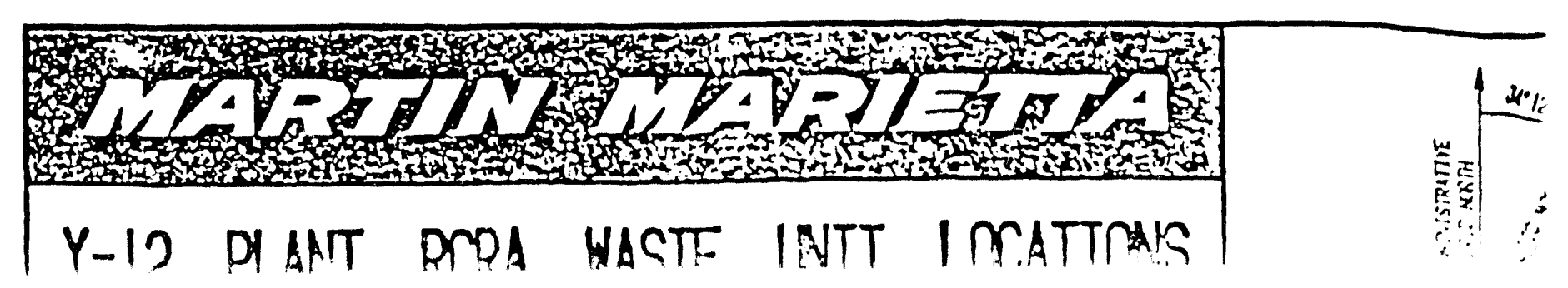





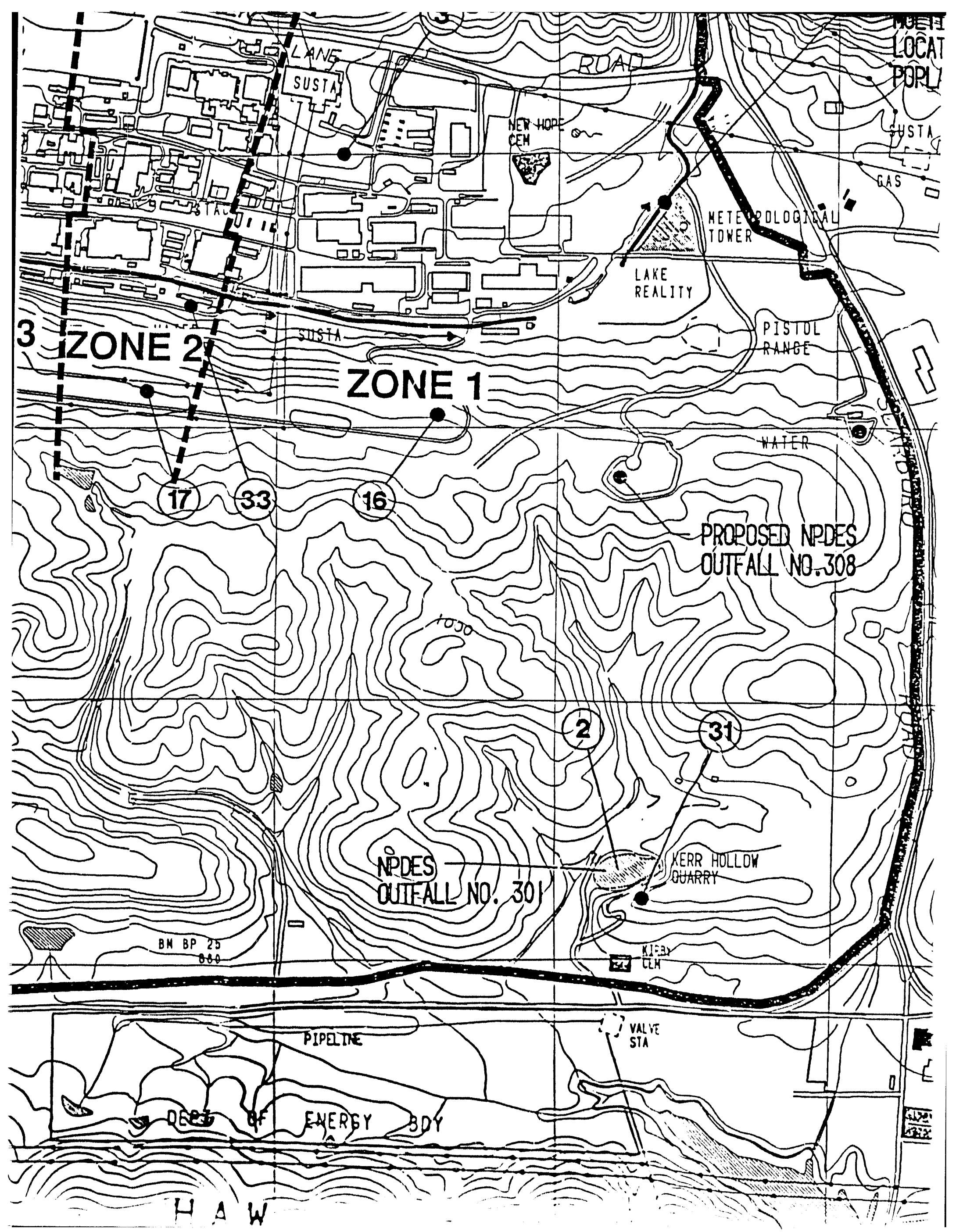




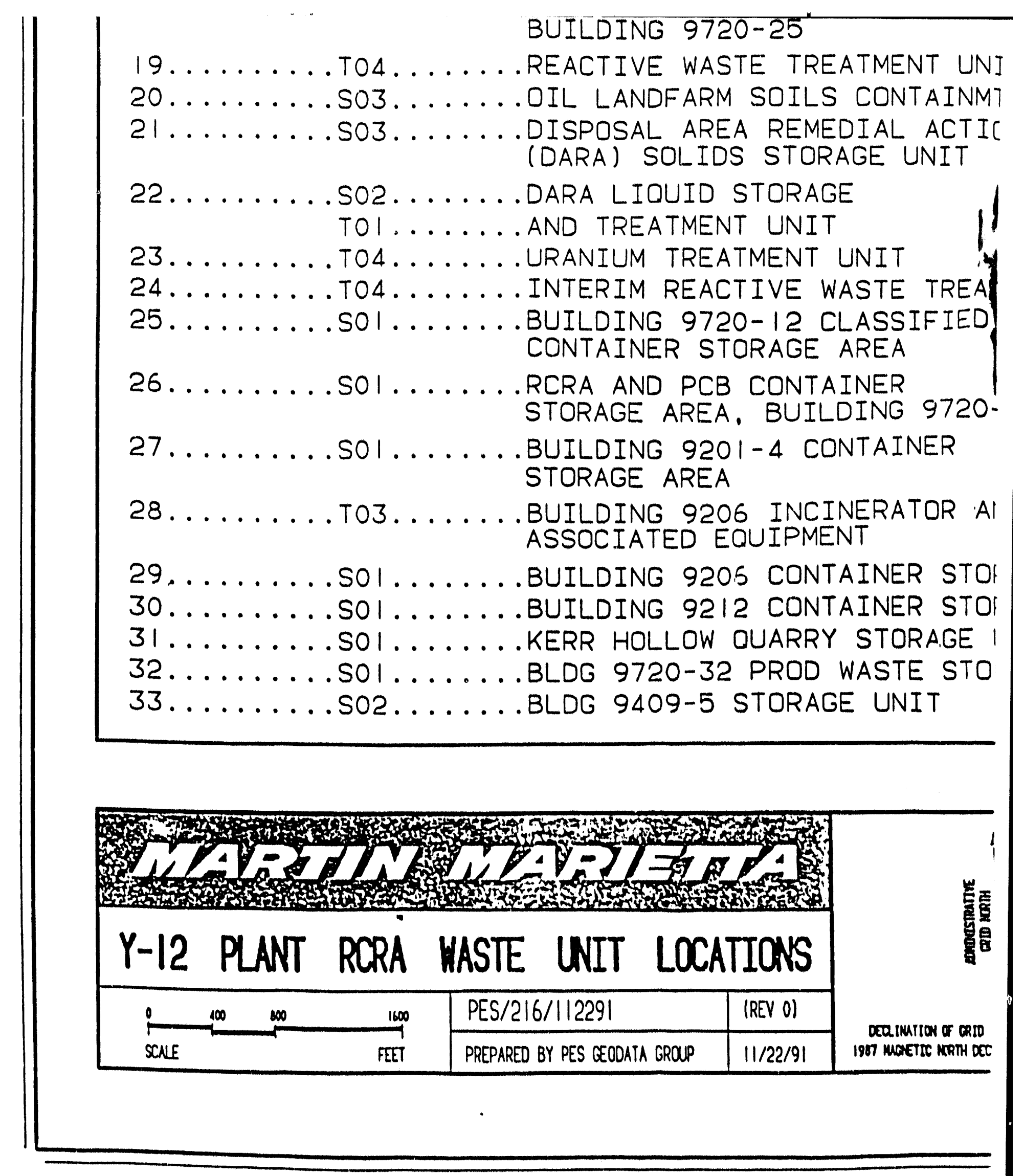




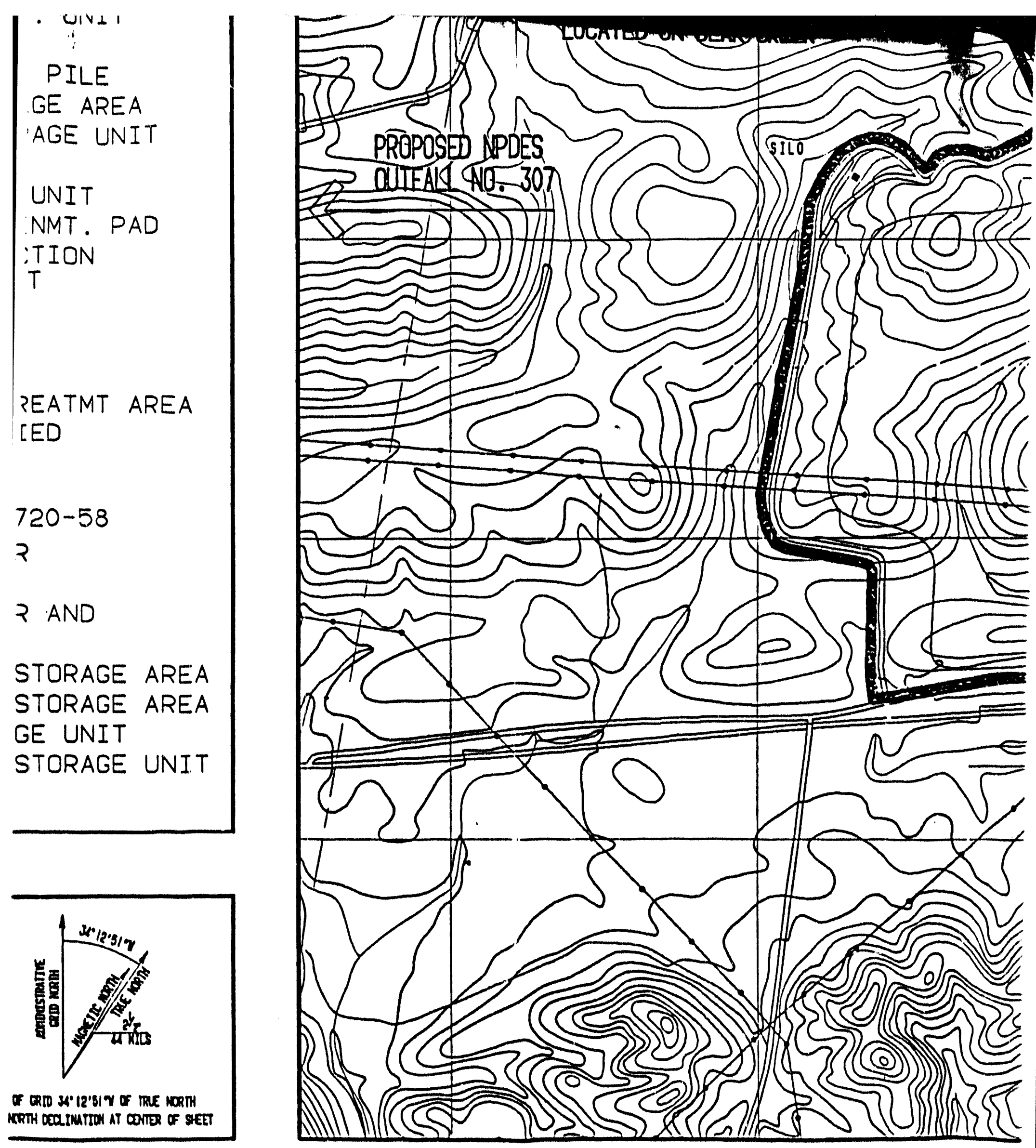




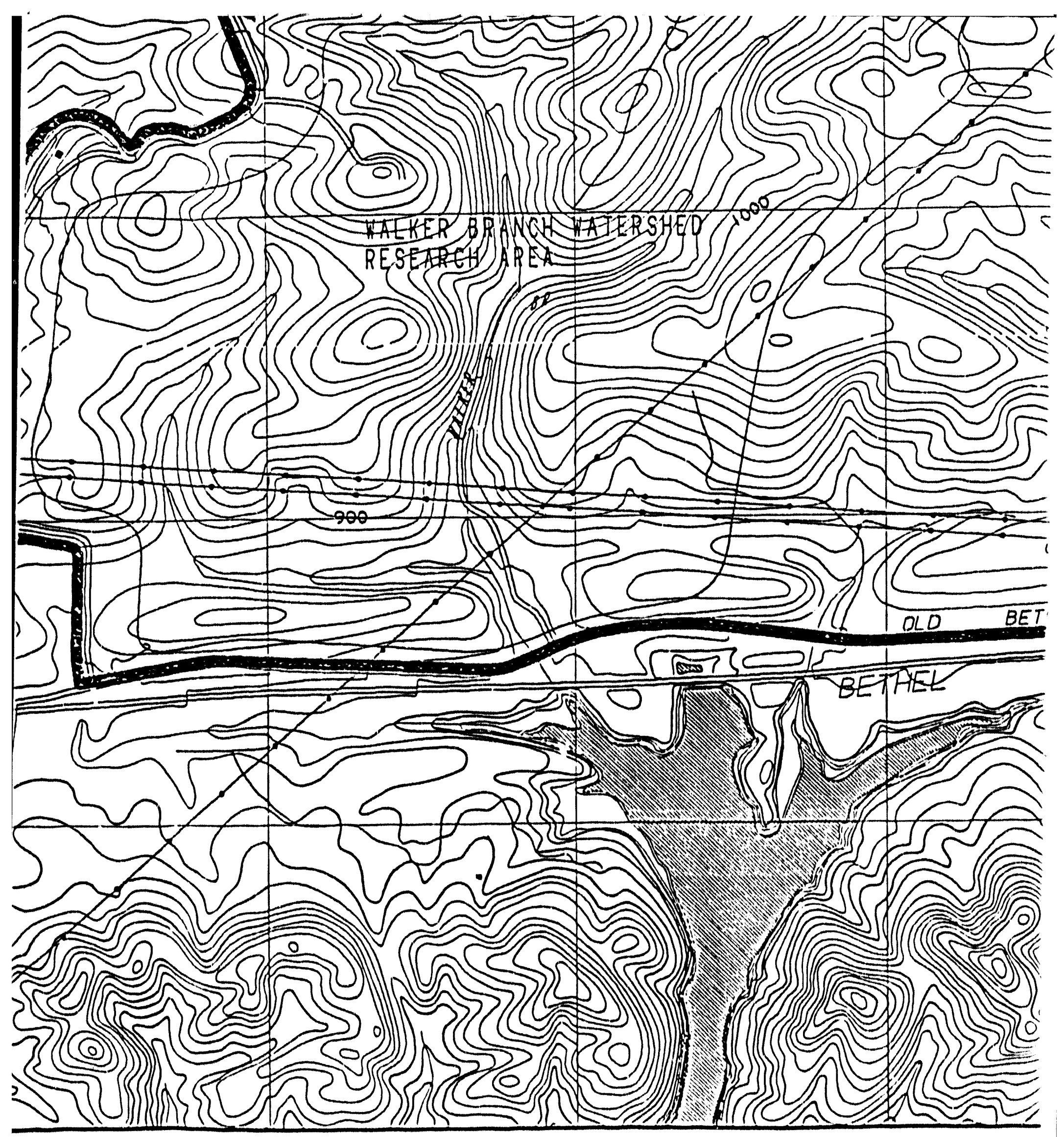




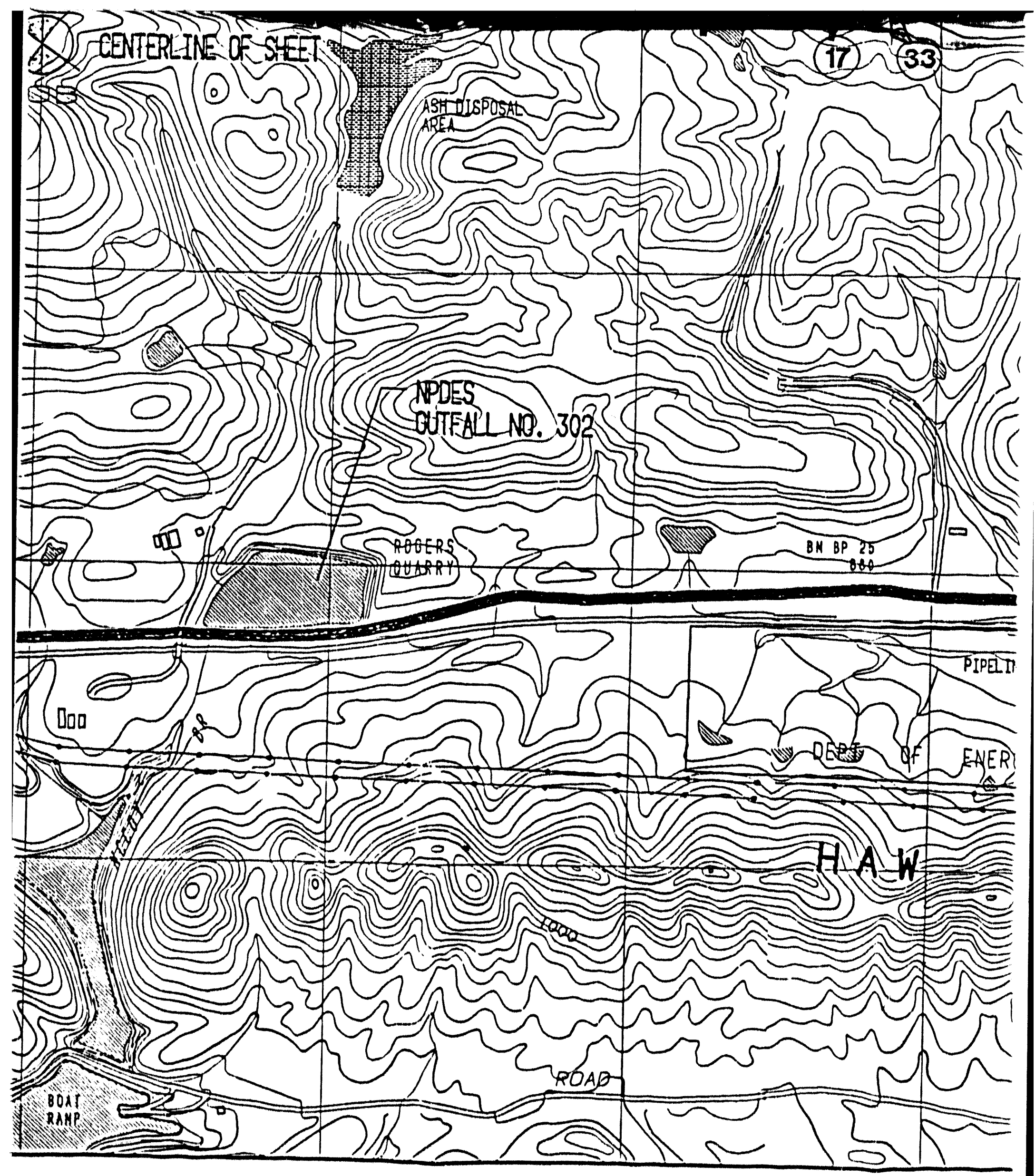




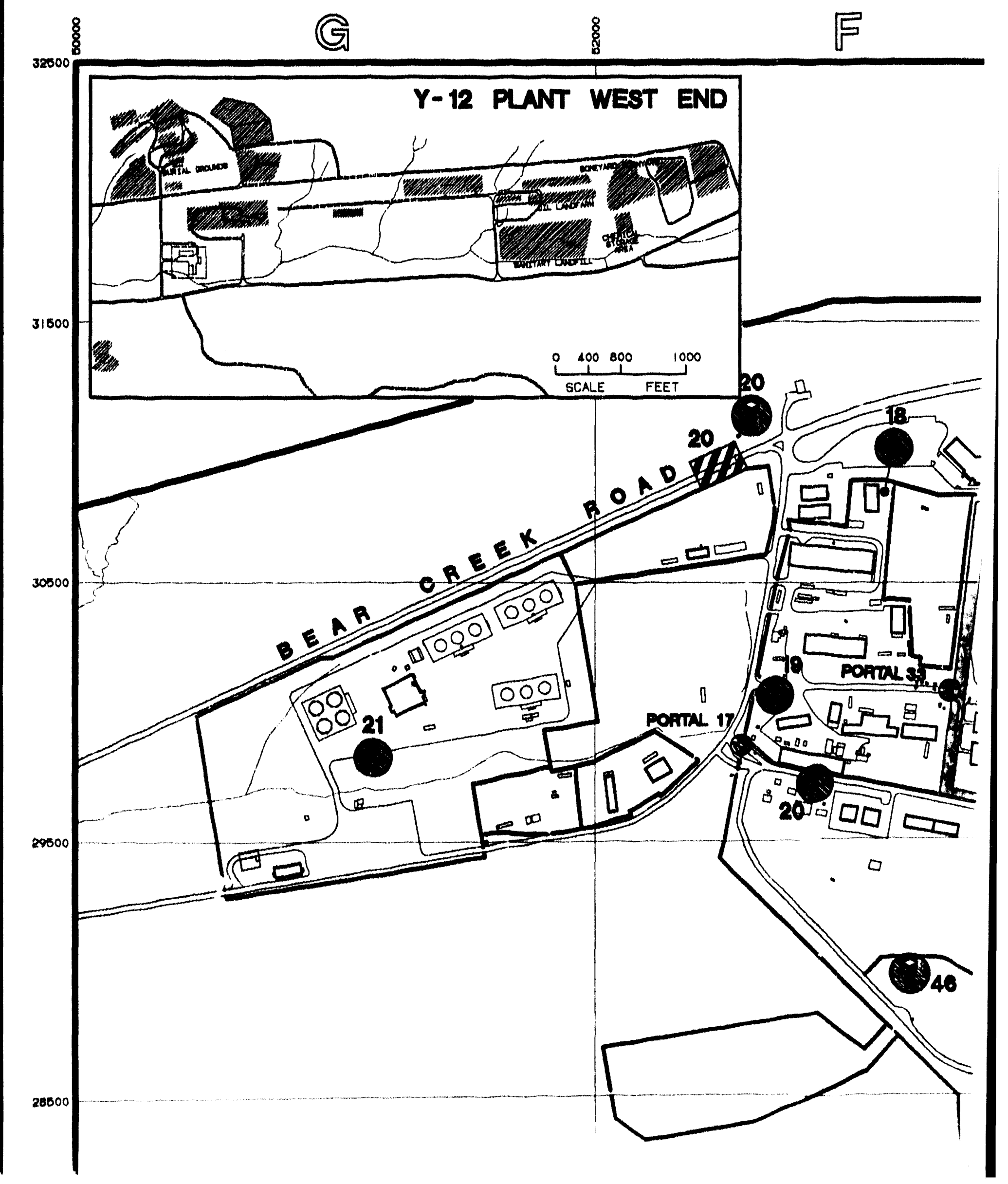




\section{OAK

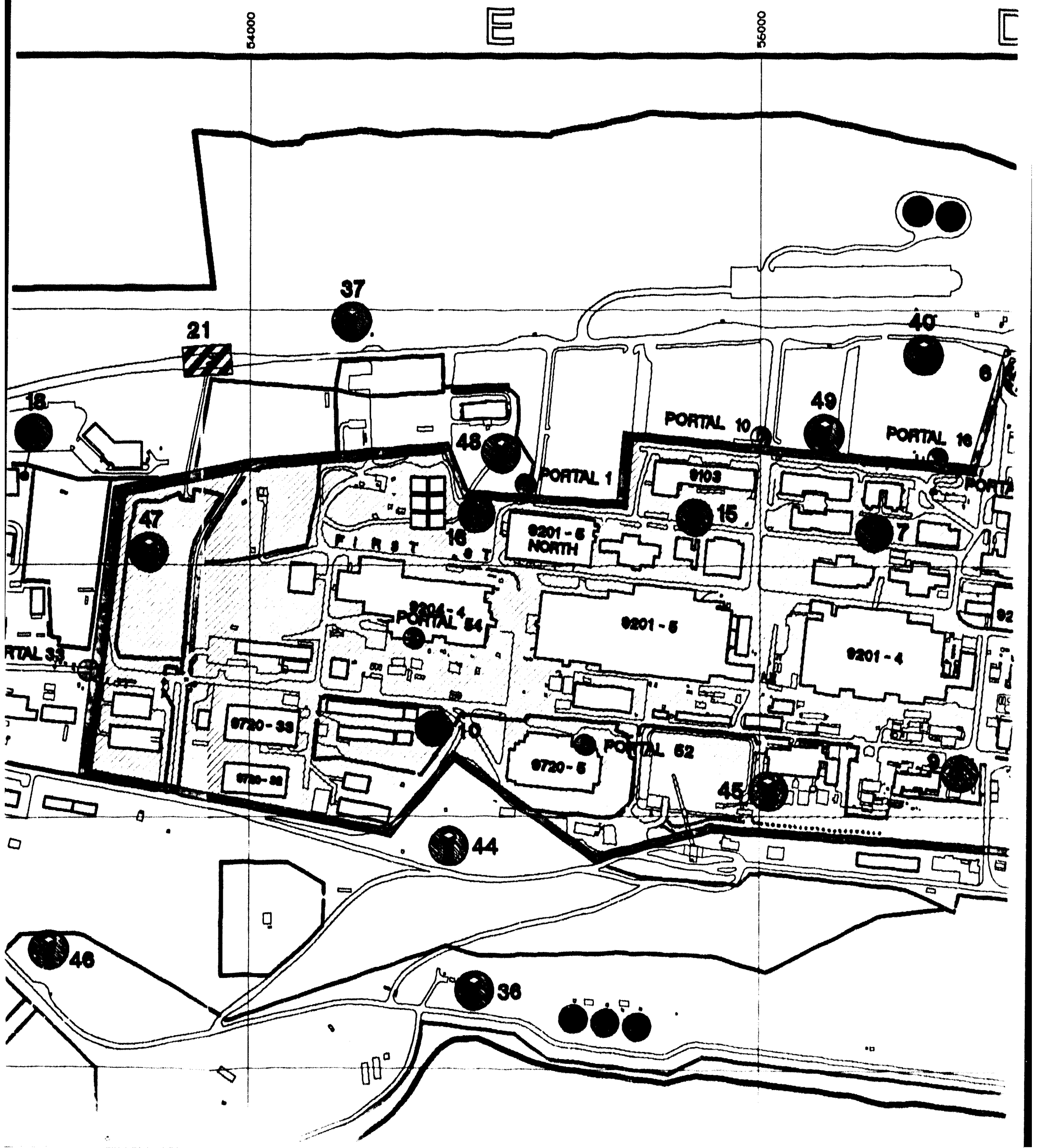




\section{JGE Y-12 FACILITIES MA}

(D)

\&

8

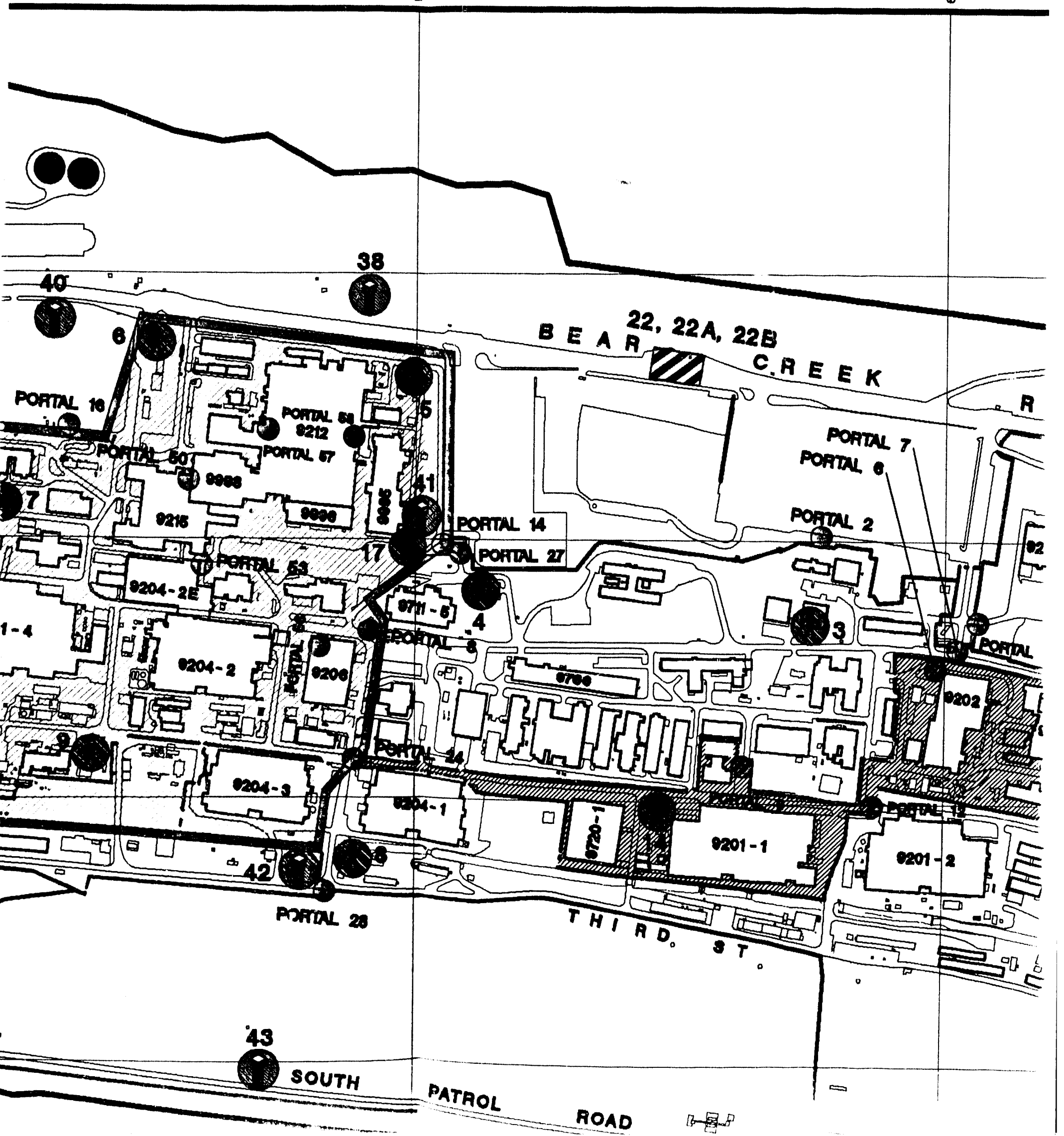




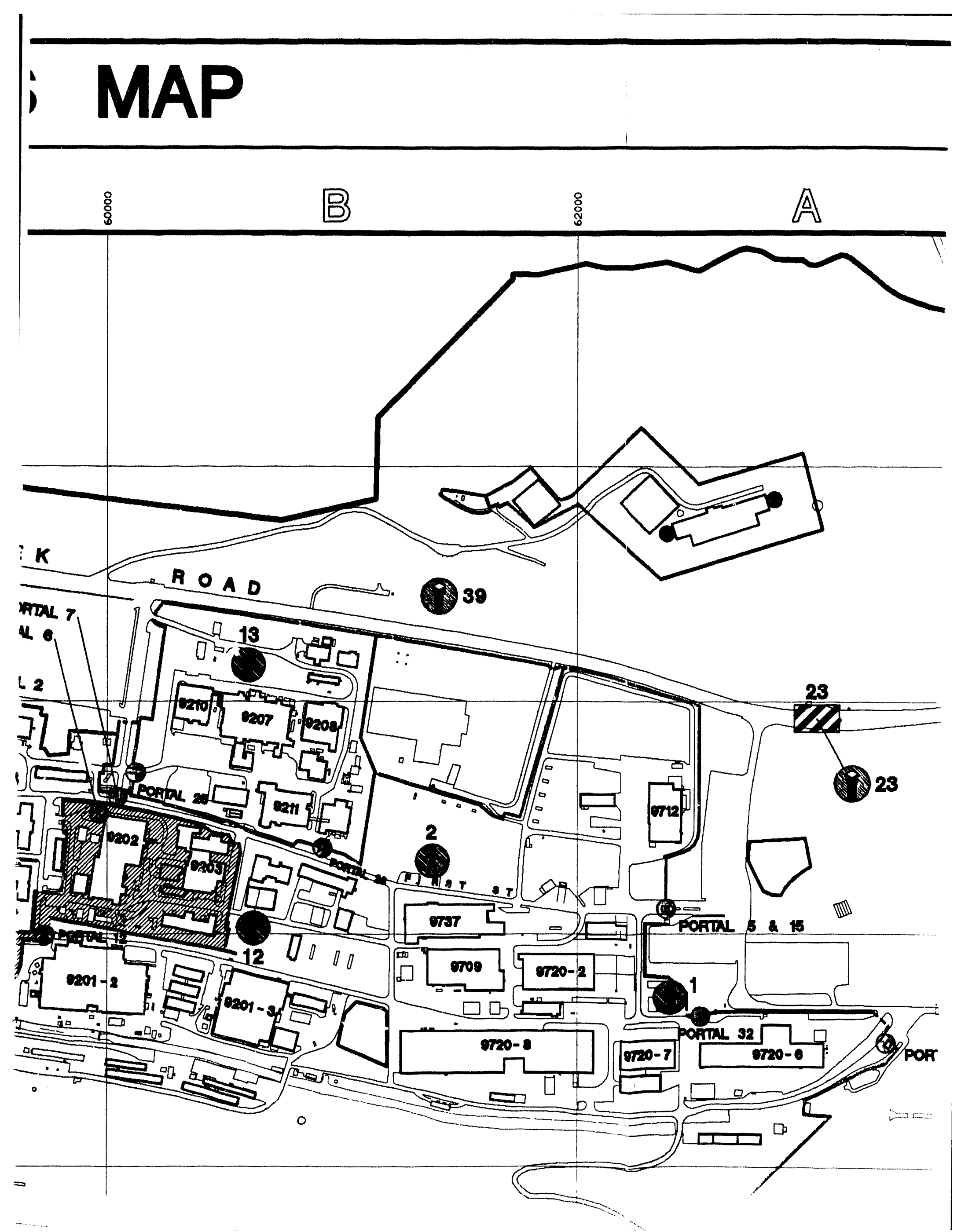




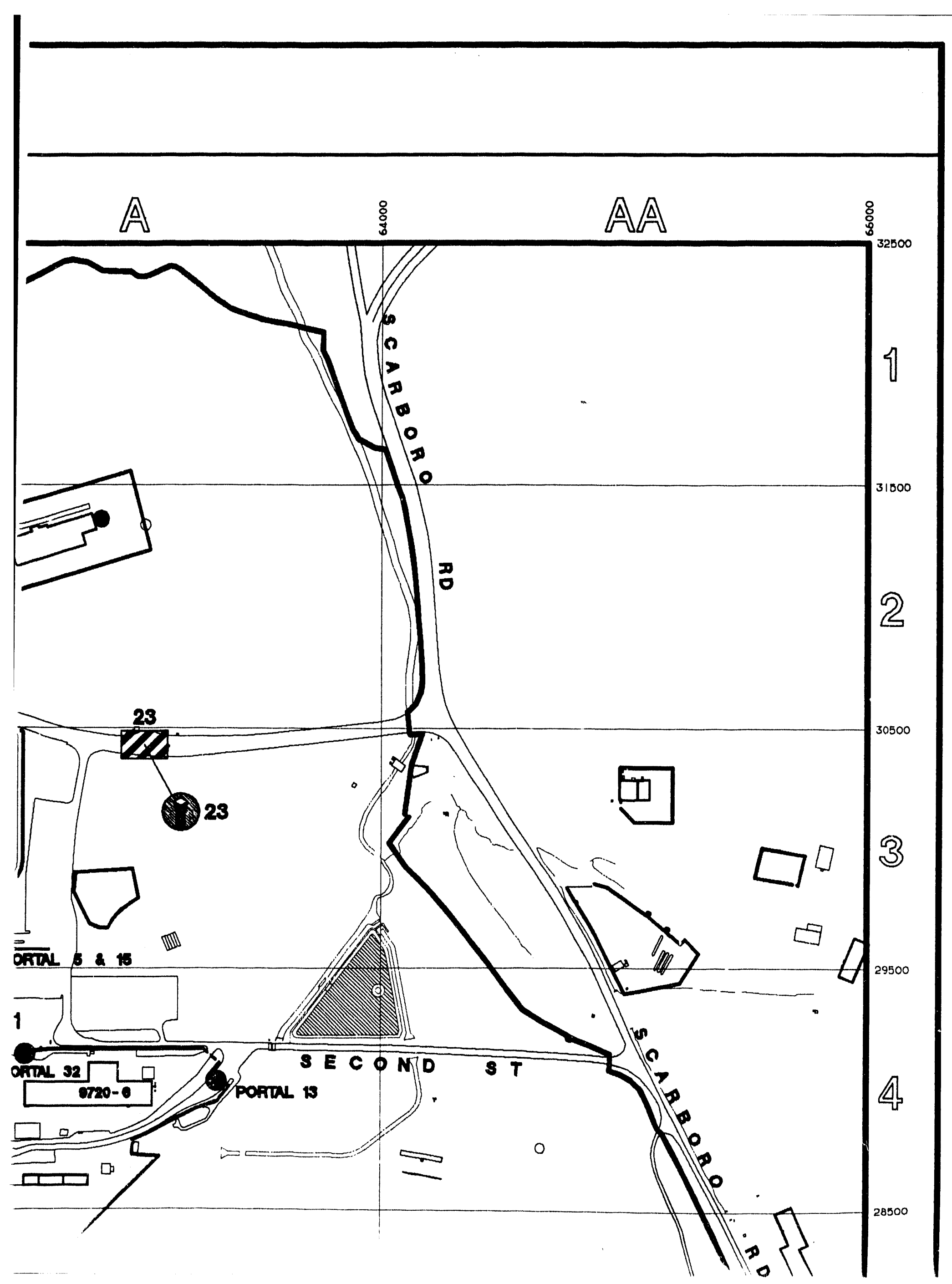



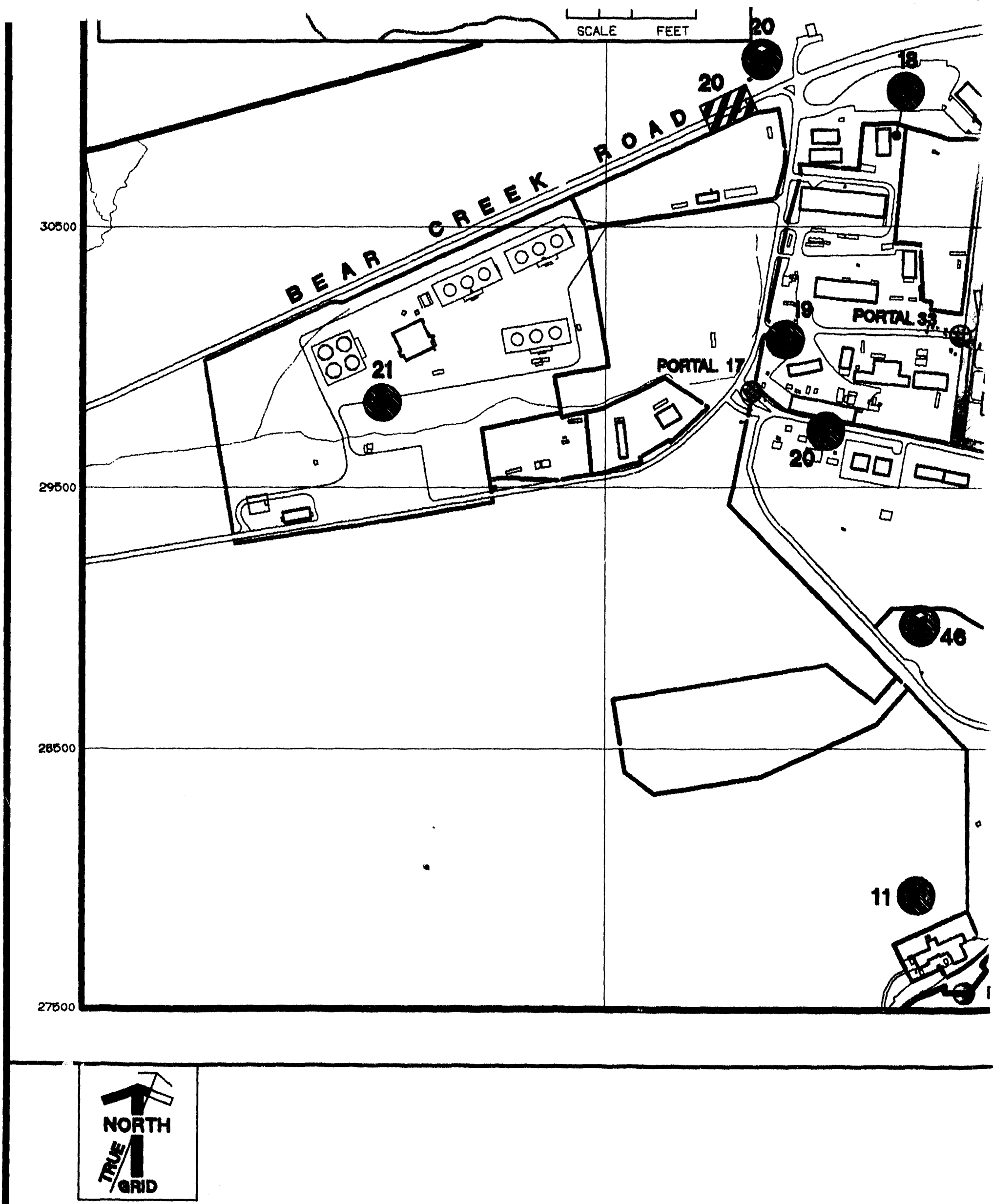

THE GRID AND COORDINATES AS SHOWN REPRESENT THE Y-I2 PLANT GRID SYSTEM 


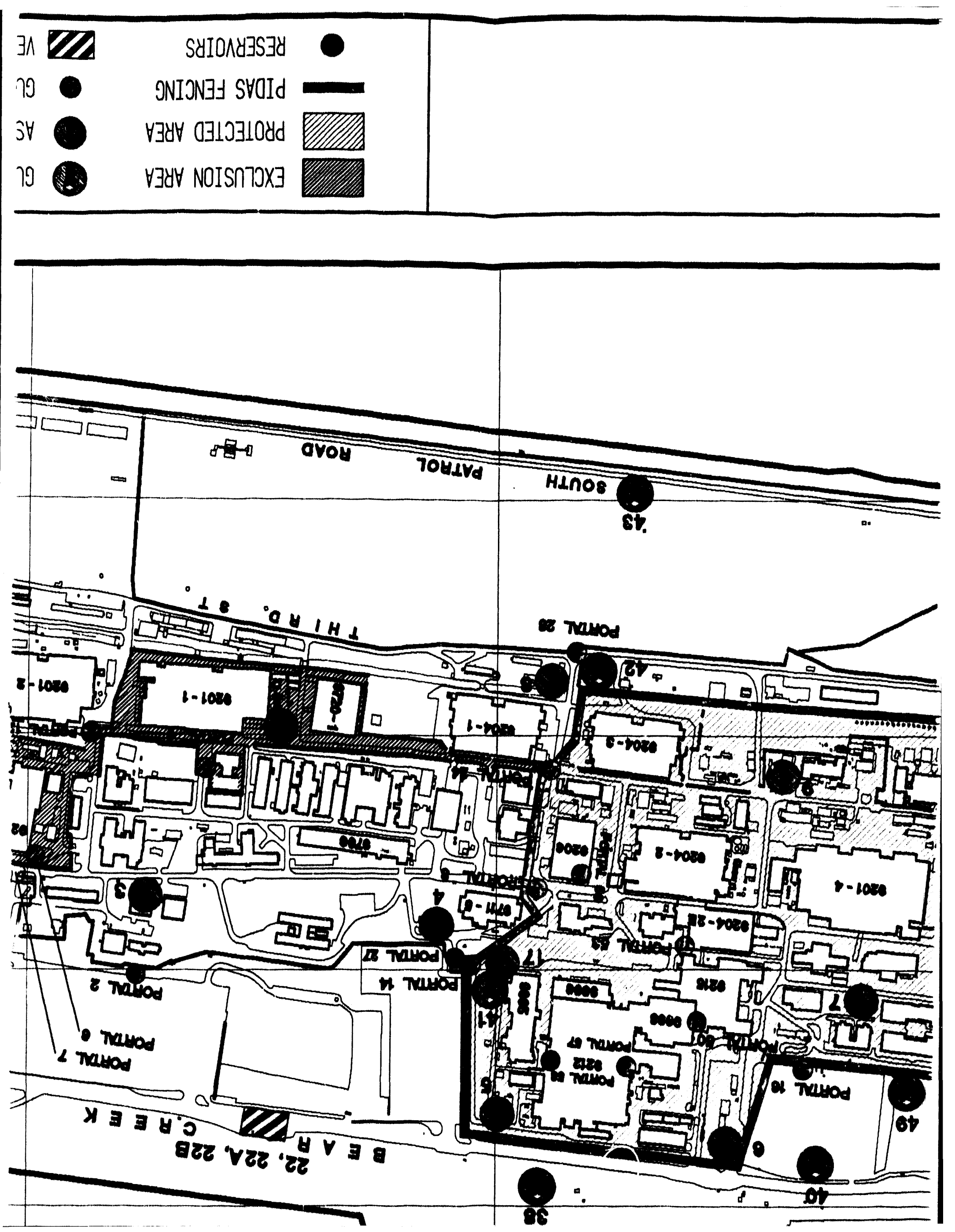




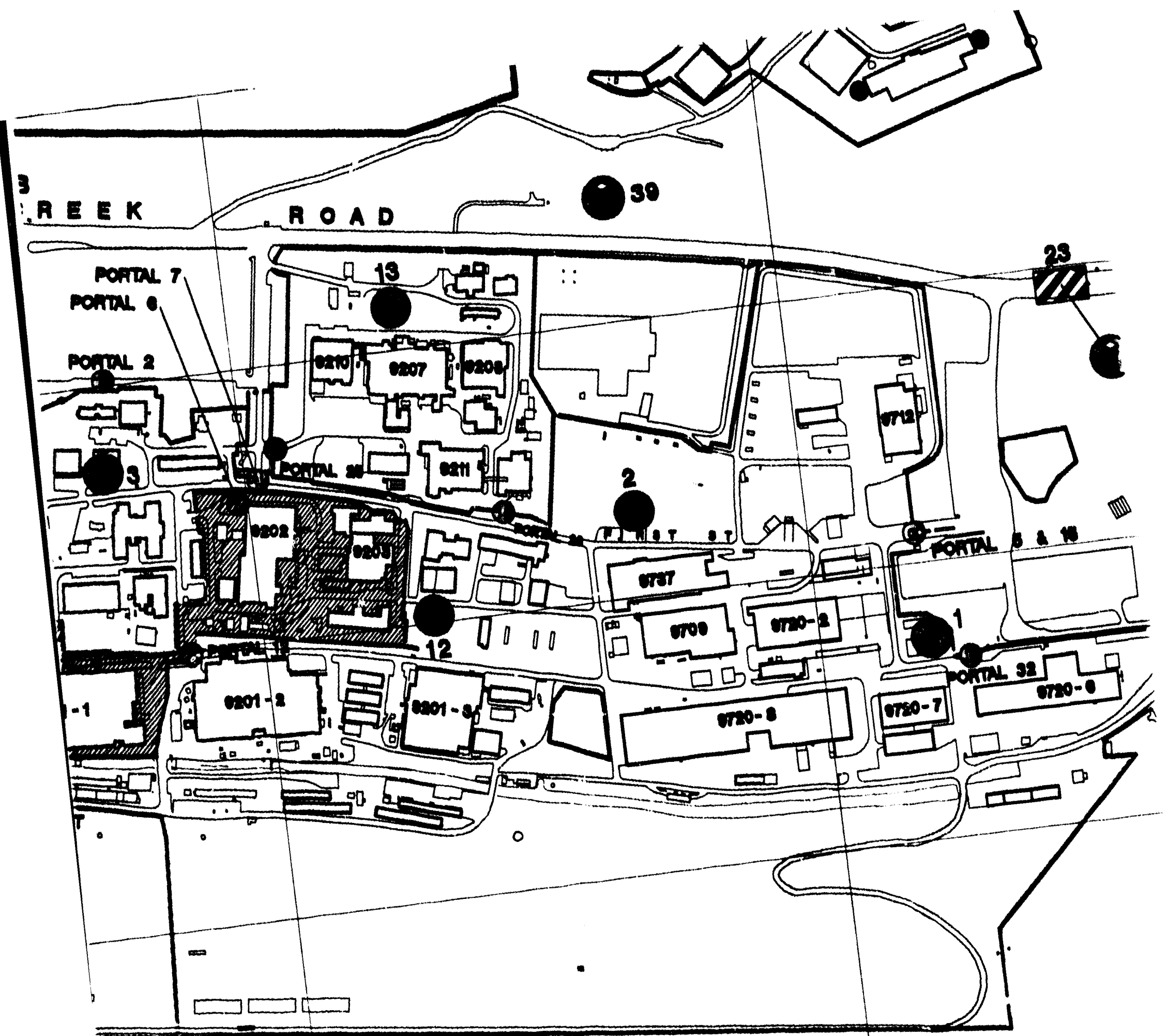




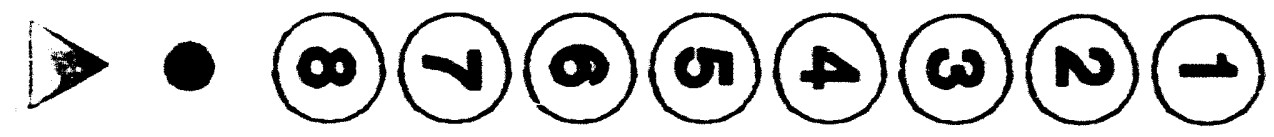

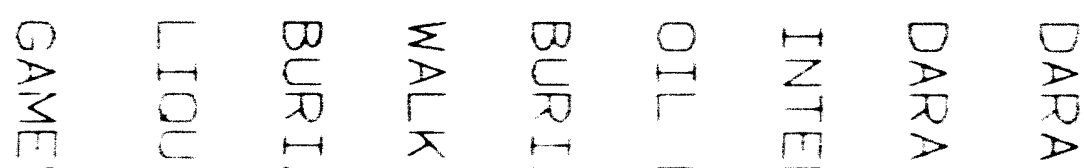

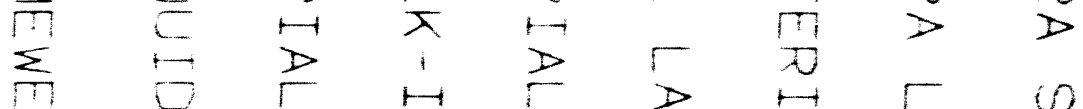

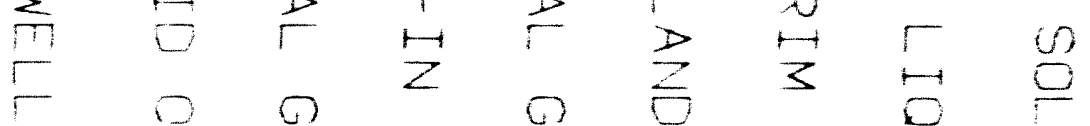

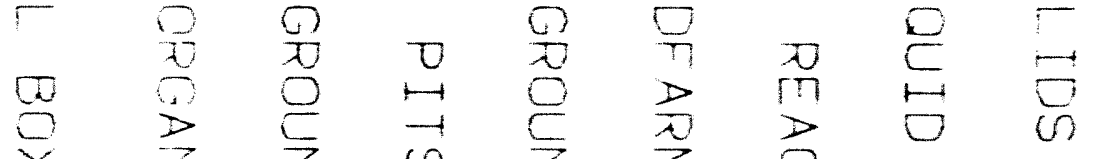

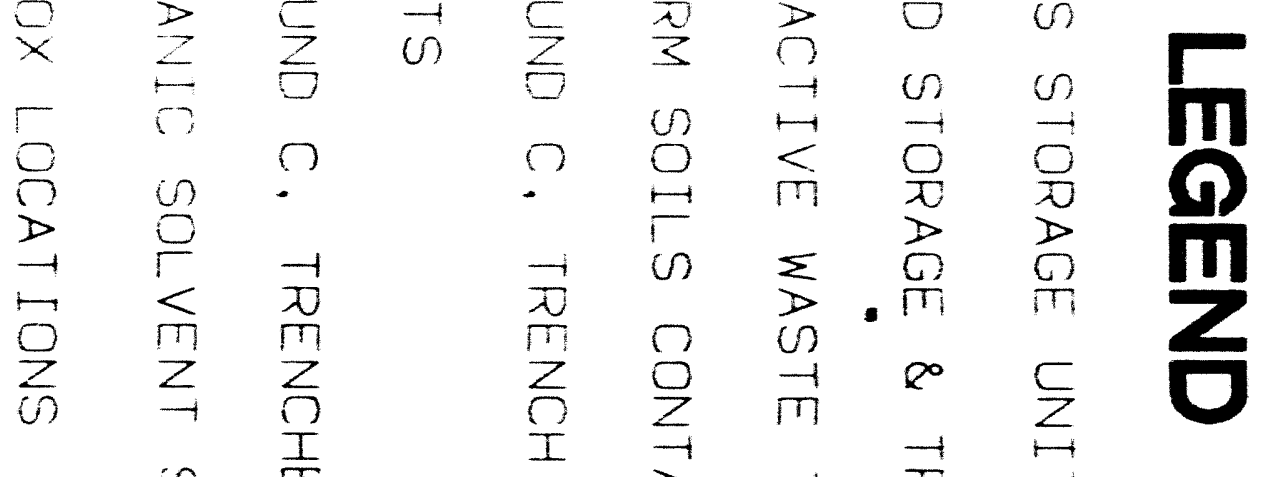

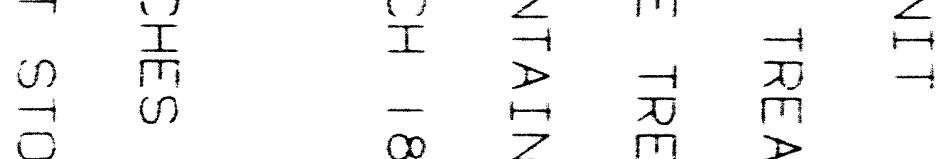

$$
\begin{aligned}
& \text { O } \\
& \begin{array}{ll}
0 & 0 \\
0 & 1
\end{array}
\end{aligned}
$$

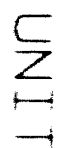
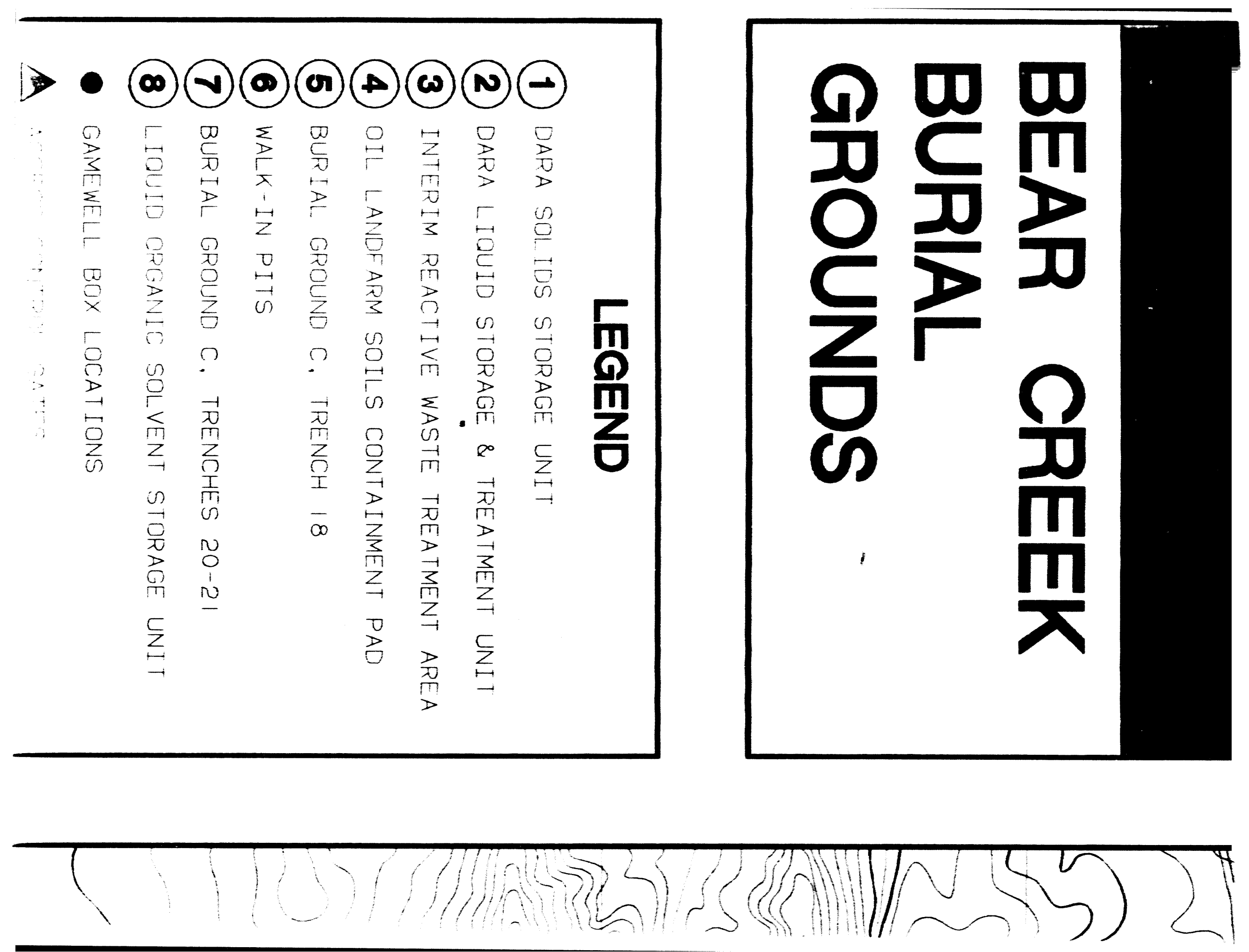


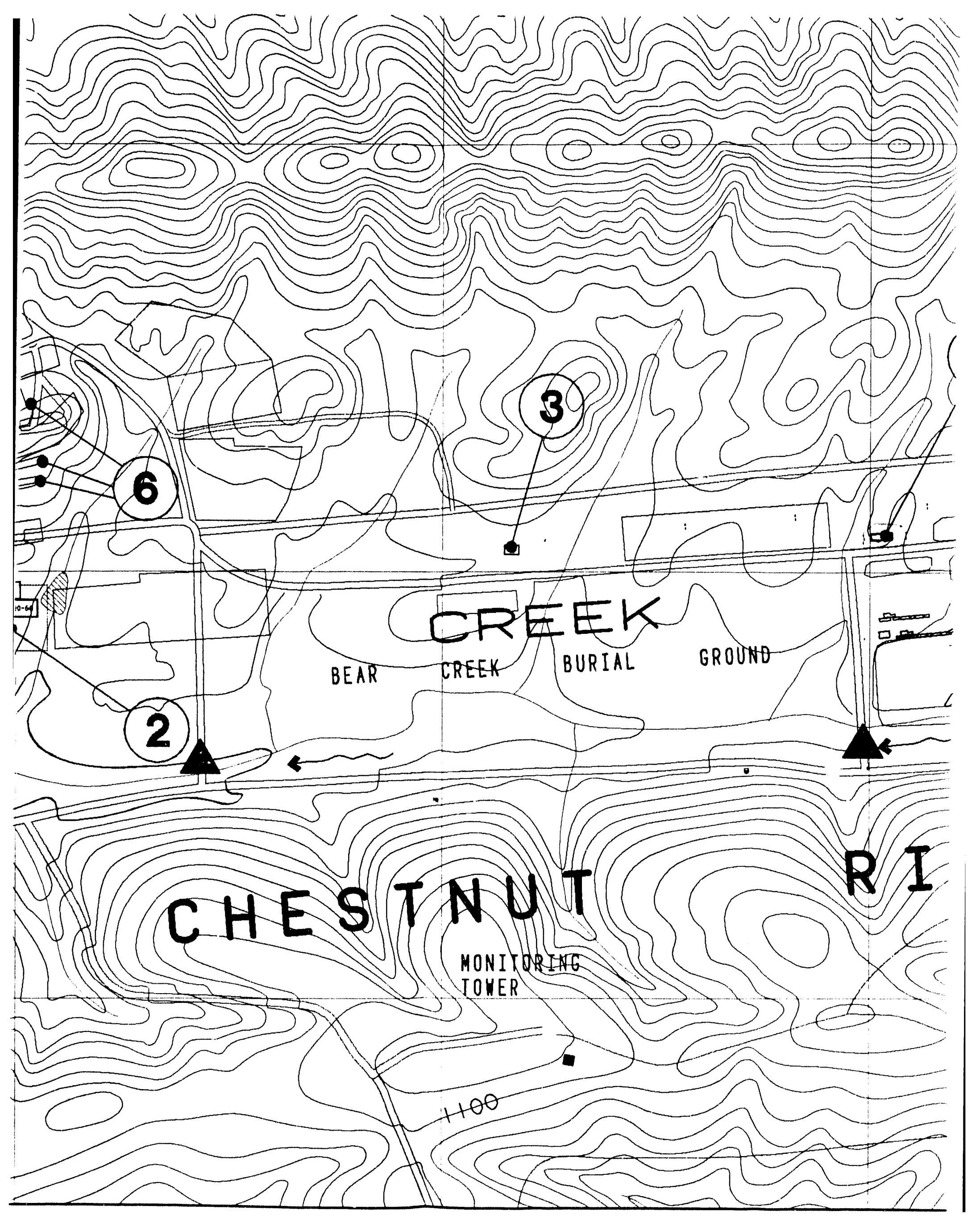




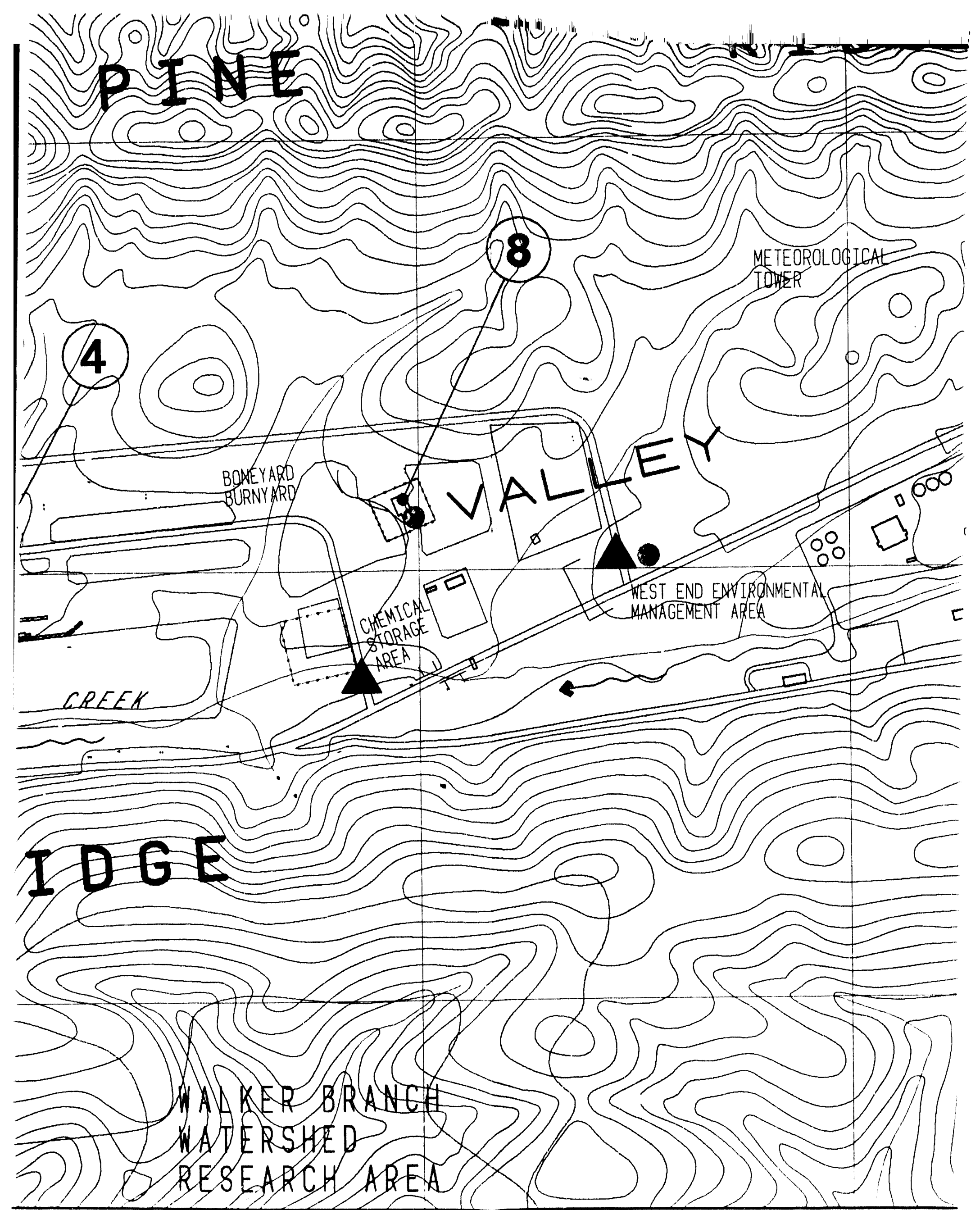


Gamewell alarm box locations. houndaries. and access controls to these areas. In the event if an emergency, the PSS will direct and inform all personnel of the evacuation routes.

\section{UNIT-SPECIFIC EMERGENCY and WASTE DESCRIPTIONS}

This section summarizes area-specific contingency and waste description information for the interim status or permitted areas/units below.

\section{Cyanide Treatment Unit}

Cyanide Treatment Unit is located in Emergency Zone 5. Building 9201-5N. The nearest Gamewell box is M534, located on the south wall outside of Building 9201-5N. This Gamewell box is connected to the existing plant Gamewell Fire Alarm System and Plant Monitoring System. A telephone is available in the room where the unit is located. An eve wash and safety shower station is also available in this room. Two-way radios are available to communicate with the PSS office if emergency assistance is necessary.

The Cyanide Treatment Unit treats cyanide wastes that have been generated in various Y-12 Plant operations including wastes from the Metal Preparation Division Plating Shops and the Precious Metals Recovery Operations (PMRO). One of the Metal Preparation Division's Plating Shops is located across the hall from the unit: the PMRO and the unit share the same basement in Building 9201-5N.

\section{Kerr Hollow Quarry Treatment Unit}

Kerr Hollow Quarry Treatment Unit is located in Emergency Zone 7, 0.4 miles west of the intersection of Pump House Road and Bethel Valley Road on the north side of Bethel Valley Road. A public address system is installed at this unit. along with closed circuit television. Two-way radios are used, and a telephone is available in the guard shack for communication with the PSS office if emergency assistance is required.

This unit no longer receives hazardous waste. It is currently undergoing closure.

\section{Garage Underground Tanks}

Garage Underground Tanks are located in Emergency Zone 1 near Building 9737. A Gamewell box is located nearby at the service station and is connected to the existing plant Gamewell Fire Alarm System and Plant Monitoring System. Two-way radios are used by personnel at this site to provide communication with the PSS ottice it emergency assistance 
is needed. A phone is available in Building 9712 East End Garage, als well as an eye wash/satety shower station.

This unit no longer receives hazardous waste. It is currently undergoing closure.

\section{Walk-In Pits}

Walk-In Pits are located in Emergency Zone 7, north of Disposal Area Remedial Action (DARA) Solid and Liquid Units. The nearest available phone. Gamewell box. eye wash and satety shower are located at DARA Liquid Storage and Treatment Unit. The Gamewell box is connected to the existing plant Gamewell Fire Alarm System and Plant Monitoring System. Two-way radios are used for communication with the PSS otfice if emergency ussistance is needed.

This unit no longer receives hazardous waste. It is currently undergoing closure.

\section{Burial Ground C. Trenches 18,20 and 21}

Burial Ground $C$ is located in Emergency Zone 7. northeast of DARA Solid and Liquid Units. The nearest available phone. Gamewell box. eye wash. and safety shower are located at DARA Liquid Storage and Treatment Unit. The Gamewell box is connected to the existing plant Gamewell Fire Alarm System and the Plant Monitoring System. Two-way radios are used for communication with the PSS office if emergency assistance is needed.

Closure is complete tor Burial Ground C. Certitication is pending.

\section{Interim Drum Yard}

Interim Drum Yard is located in Emergency Zone 6, near Building 9720-32. The nearest available Gamewell box is M612, located on the east end of Building 9720-32. This Gamewell box is connected to the existing plant Gamewell Fire Alarm System and the Plant Monitoring System. A portable eye wash and safety shower are used by personnel at this unit. Two-way radios are used for communication with the PSS if emergency assistance is needed. and a phone is also available nearby in Building 9401-5.

The closure plan has been submitted for this unit. Approval and closure activities are pending. 


\section{Building 9720-9, Storage Linit}

Building $9720-9$ is located in Emergency Zone 5. on Third Street. Two Gamewell boxes are located at the east and west sides of the building and are connected to the existing plant Gamewell Fire Alarm System and the Plant Monitoring System. Telephones and two-way radios are also used by personnel to provide communication with the PSS office if emergency assistance is needed. Two eye wash/safety showers are provided and are located at the west and south sides of the building.

This unit is a storage facility for hazardous and nonhazardous waste and is a long-term storage facility for uranium contaminated tlammables. Waste is stored at this facility for uranium contaminated flammables. Waste is stored at this facility until waste analysis and appropriate disposal (bulk storage and/or otf-site shipment) can be arranged. All classes of RCRA wastes. except for " $K$ " wastes. hazardous wastes trom specific sources ( 40 CFR 261.32 and TN Reg. 1200-1-11.02(4)) are stored in this unit

\section{RCRA and Mixed Waste Storage and Staging Únit. Building 9720-31}

Building 9720-31 is located in Emergency Zorty 6. on West Third Street. Two Gamewell boxes are located on the east and west side of the building and are connected to the existing plant Gamewell Fire Alarm System and the Plant Monitoring System. Telephones and twoway radios are also used by personnel to provide communication with the PSS offices if emergency assistance is needed.

This unit is also known as the "RCRA Motel" and is used to store solids. liquids. and sludge wastes. It is a one-story structure constructed of light weight concrete block masonry walls and partitions. The building is partitioned into 15 rooms: one supply room. seven staging rooms, and seven storage rooms. Normally, the largest containers in any of the staging or storage rooms are 55-gallon drums, however, 85-gallon overpack containers may be used to store waste. Waste stored in the staging and storage rooms may be in Department of Transportation specification containers or in the original product containers.

\section{Building 9811-1 RCRA Tank torage Unit (OD-7)}

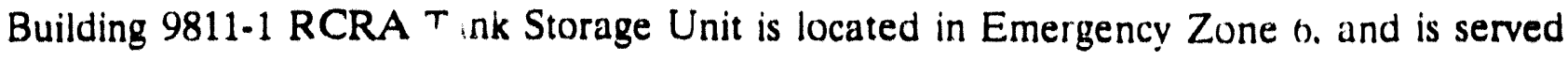
by an auxiliary tire alarm pull box (SO number $6877-500$ ), which is inside the south side of 9811-1. Additional alarm boxes are located at Building 9720-16. Box P635. and at the intersection of Second Street and K Road which is southwest of OD-7. Box 031. These 
boxes are connected to the existing plant Gamewell Fire Alarm System and the Plant Monitoring System. Two tire hydrants are located near this unit. One is approximately 20 teet north of the RCRA Storage Unit and the second hydrant is located approximately 75 teet southwest. Telephones and two-way radios are used by personnel to provide communication with the PSS office if emergency assistance is needed. A telephone is also located in the OD-7 operator trailer for communication with emergency personnel. A satety shower/eyewash assembly is planned for installation at a future date at the drum loading/unloading area and the transfer station as part of an OD.7 upgrade project.

This unit is designated as the primary storage unit for nonignitible and nonreactive uranium contaminated waste oils and solvents. PCB contaminated oils less than $50 \mathrm{ppm}$, as well as non-chlorinated solvents and some additional metals contaminated wastes. may also be accepted at the unit.

The storage tank area of the unit consists of a $51 \times 58$ concrete diked area. Positioned within the diked area are tour 30.000 gallon tanks (F-1, F-2, F-3, F-4) and one 10.000 gallon tank (F-7). Two additional 10.000 gallon tanks (F.5 and $F \cdot 6$ ) will be installed at a future date.

\section{Building 9811-1 - RCRA Container Storage Unit (OD-8)}

Building 9811. ${ }^{\circ}$ is located in Emergency Zone 6, at the intersection of West Second Street and $\mathrm{K}$ Road. A Gamewell box is located on the south side of the building (inside) and is connected to the existing plant Gamewell Fire Alarm System and the Plant Monitoring System. A safety shower/eye bath is located at the north side of the building.

This unit is used primarily as a staging area for containerized liquid waste until the waste has been characterized to allow transfer to other TSD units. Since the dike height does not meet minimum height requirements (six inches) of TSCA regulations. PCB contaminated liquids will not be stored at this unit.

\section{Building 9212 Tank Farm}

Building 9212 Tank Farm is located in Emergency Zone 4. Telephones are available in the area control room and the office trailer located nearby, at the northeast corner of a ninety day temporary accumulation area. Two-way radios are also used to communicate with the 
PSS : ffice if ent rgency assistance is needed. The adjacent ninety day area also contains a satety shower and eve bath station.

A permit-by-rule was submitted in April 1992 for this unit. Approval from the Tennessee Department of Environment and Conservation (TDEC) is pending.

\section{Waste OillSolvent Storage Unit (OD-9)}

OD.9 is located in Emergency Zone 7 and is served by an auxiliary fire alarm pull box (Gamewell Box Number 712). The Gamewell box is connected to the existing plant Gamewell Fire Alarm System and the Plant Monitoring System. Two fire hydrants are available for use each having a working pressure of 175 psig, a six inch valve, and are freezeproot. One hydrant is located along the site access road approximately of) feet east of the truck entrance to the building. The second hydrant is on the north side of Old Bear Creek Road. near the site egress road, approximately 100 feet southwest of the facility truck exit area. Telephones and two-way radios are used by personnel to provide communication with the PSS office if emergency assistance is needed. Two safety shower/eye wash assemblies, both of which are freeze-proot. are located at the northeast corner of the tank area (in the truck loading pad adjacent to the drum storage area) and on the floor of the containment structure. l'otable water is supplied from a service line to both units, and are identified by green lights nstalled above each unit. The eye/face units are push bar operated with stayopen valves.

This unit typically receives and stores nonignitible and nonreactive waste oil/solvents that may contain water, may be contaminated with PCBs greater than $50 \mathrm{ppm}$ and uranium, and may contain chlorinated organic solvents. The liquid wastes are stored here in tanks and drums until sufficient volume is accumulated for transportation to an outside facility for recovery or disposal.

\section{Biodenitrification Unit}

Biodenitrification Unit is located in Emergency Zone 4, near Building 9212 and Building 9818. Telephones are located in the 9818 control room and the office trailer located at the northeast corner of a nearby ninety day temporary accumulation area. Two-way radios are also used to communicate with the PSS office if emergency assistance is needed. Two Gamewell boxes are located on the first tloor of Building 9818. One is located on the west wall just outside the 9818 control room. The second box is located at the northeast exit 
from the building. These Gamewell boxes are connected to the existing plant (jamewell Fire Alarm System and the Plant Monitoring System.

I permit-by-rule was submitted in April 1992 for this unit. Approvil trom the TDEC is pending.

\section{Liquid Organic Solvent Storare Unie (OD.10)}

OD. 10 is located in Emergency Zone 7, and is served by an auxiliary tire alarm pull box which is located approximately 40 feet south of the tacility. An additional Gamewell box (. Number 714 ) is accessible at the intersection of Bear Creek Road and the access road to OD.10. This Gamewell box is connected to the existing plant Gamewell Fire Alarm System and Plant Monitoring System. A treeze-proot fire hydrant is located approximately 200 feet south of the tacility which is supplied by an 8-inch malleable iron water main connected to the 24-inch main that runs along Bear Creek Road. Two-way radios provide communication between the facility and the PSS office if emergency assistance is necessary. Three safety shower/eye wast assemblies are provided at OD:10 which includes two located in the staging area (north and south side) and the third located in the tank area. Potable water is supplied to these assemblies which are push bar operated with stay-open valves. Each unit is identitied by a green light installed above each assembly.

This unit receives and stores liquid organic wastes generated in the $Y .12$ Plant and is currently operating in accordance with RCRA Permit Number TNHW-20. These wastes typically include waste oil and combustible and tlammable waste liquids that may contain trace quantities of uranium. The liquids received at this unit are pumped into the tanks for storage until sufficient quantity is accumulated for tinal disposal or recovery.

\section{Building 9409-5 Storage Unit}

Building 9409-5 Storage Unit is located in Emergency Zone 2. The nearest Gamewell box is P396. located in Building 9409-2. This Gamewell box is connected to the existing plant Gamewell Fire Alurm System and Plant Monitoring System. No phone is available. and this unit is no longer in service. Two-way radios are used to communicate with the PSS office it emergency assistance is needed.

This unit no longer receives hazardous waste. It is currently undergoing closure. 
$8 / 21 / 92$

Rev. 1.2

\section{East Chestnut Ridre Waste Pile}

East Chestnut Ridge Waste Pile is located in Emergency Zone 1. un East Patrol Road. Two-way radios are used to communicate with the PSS office if emergency assistance is required. The nearest Gamewell box. M115. is located north of Building 9720).8. This Gamewell box is connected to the existing plant Gamewell Fire Alarm System and Plant Monitoring System.

This waste pile is used for the temporary storage of soils and spoils contaminated with hazardous and low-level radioactive materials. asbestos. and rooting materials trom the closure of RCRA sites at the $Y \cdot 12$ Plant. Additional contaminated soils may he moved to ECRWP if excavation activities continue at $Y-12$. The unit is currently inactive.

\section{Cuntainerized Waste Storage Area (CWSA)}

The CWSA is located in Emergency Zone 2. on South Patrol Road. A Gumewell box is located south. directly across the street from the CWSA and is connected to the existing plant Gamewell Fire Alarm System and the Planit Monitoring System. Two-way radios are also used to provide communication with the PSS office if emergency assistance is needed. A portable satety shower/ eyewash is provided during operations.

The CWSA consists of three concrete pads measuring 170 feet long and 50 feet wide. The central and eastërn concrete pads are covered by open-sided dome tents and store low-level radioactive-contaminated, RCRA hazardous waste, and/or mixtures of these wastes. The western concrete pad is not covered, and no wastes have been stored there. Each pad has a one-foot impermeable dike surrounding it to contain spills. The pads and dikes are sloped toward a 60-gallon sump located on the southeast corner of the pads to catch spilled material and for the management of rainwater run-on.

\section{Classified Container Storage Unit. Building 9720.25}

Building $\mathbf{9 7 2 0 - 2 5}$ is located in Emergency Zone 6, on M Street. Two Gamewell boxes are located inside the building and are connected to the existing plant Gamewell Fire Alarm System and the Plant Monitoring System. Telephones and two-way radios are also used by personnel to provide communication with the PSS office if emergency assistance is needed.

Building $9720-25$ is a storage unit designed for temporary storage of classified wastes generated at the $Y \cdot 12$ Plant. The wastes include materials. fabricated parts. and containers 
which have been security classified in prevent dissemination of potentially vilial intormation. Storage in one part of this unit of classitied waste. contaminated with hazardous constituents. is necessary due to present uncertainties as to tinal modes of treatment andior disposal of classitied and/or hazardous waste materials. The stored materials include RCRA hazardous. low-level radioactive. and mixed wastes.

\section{Qil Landfarm Soils Containmens Pad}

Oil Lundfarm Soils Containment Pad is located in Emergency Zone 7. west of the main plant area on Bear Creek Road. A telephone is available nearby in the sampling trailer, or iwo-way radios are used to communicate with the PSS utfice if emergency assistance is needed. The nearest eye wash/satery shower station is located at the Liquid Organic Solvent Storage L'nit. which lies west of this location on Bear Creek Road.

This unit provides long-term storage for contaminated soils and excavation wastes that were generated during RCRA closure of the Oil Landfarm and Oil Retention Ponds at the Y-12 Plant. These soils were contaminated with hazardous. mixed. or radioactive wastes. Contaminants include organics. heaw metals. pesticides. PCBs. and low levels of depleted uranium. The unit provides interim storage tor excavation wastes pending scheduling of the soils for tinal treatment or disposal. This unit is currently inactive.

\section{Disposal Area Remedial Action (DARALSolids Storage Unil (SSU)}

DARA Solids Storage Unit is located in Emergency Zone 7, west of the main plant area on Bear Creek Road. A Gamewell box is located near the unloading pad adjacent to DARA Solids at DARA Liquid Storage and Treatment Unit. This Gamewell box is connected to the existing plant Gamewell Fire Alarm System and Plant Monitoring System. A telephone is available in the operator's trailer south of DARA Liquid Storage and Treatment Unit, and two way radios are also used to communicate with the PSS office if emergency assistance is needed. Eye wash/satery shower stations are available on the unloading pad at DARA Liquid Storage and Treatment Unit.

The DARA SSU provides temporary storage for contaminated sediments and excavation wastes generated during closure of the Oil Retention Ponds. These sediments are contaminated with PCBs and VOCs. They will be stored in the DARA SSU until they can he scheduled for tinal treatment or disposal. This unit is currently inactive. 


\section{DABA Liquid Storage and Treatment Unit}

DARA Liquid Storage and Treatment Unit is located in Emergency Zone 7 west of the main plant area on Bear Creek Road. A Gamewell box is located near the unloading pad It DARA Liquid Storage and Treatment Unit. This Gamewell box is connected to the existing plant Gamewell Fire Alarm System and Plant Monitoring System. A telephone is available in the operator's trailer south of DARA Liquid Storage and Treatment Unit, and two-way radios are also used to communicate with the PSS office if emergency assistance is needed. Eye wash/satety shower stations are available on the unloading pad at DARA Liquid Storage and Treatment Unit.

A permit-by-rule was submitted for this unit in March 1992. Approval from the TDEC is pending.

\section{Interim Reactive Waste Treatment Area (IRWTA}

The IRWTA is located in Emergency Zone 7 west of the main plant area on Bear Creek Road. and is served by an auxiliary fire alarm pull box near the trailers at the Closed Sanitary Landfill 1. Twn-way radios are used tq provide communication with the PSS office if emergency assistance is needed. Portable evewash systems are used during operation. In addition, the $\mathrm{Y}-12$ Fire Department is at the unit during the thermal treatment process to assist, if needed.

This interim unit was designed for the thermal treatment of sodium potassium (NaK) generated during maintenance activities at the $\mathrm{Y}-12$ Plant. The unit currently operates in accordance with an Open Burning Permit No. 01-00020-00001. It is used approximately once per year dependent upon the generation of NaK wastes. A NaK burn hasn't taken place in almost two years. The NaK is water reactive. This means that it reacts violently with water. If the $\mathrm{NaK}$ does come in contact with the water, it will react. thus rendering it nonhazardous. To prevent this from occurring, a 3 feet by 5 feet steel pan is used to provide secondary containment for the pail during interim burning. The Fire Department is also present until the duration of the burn to ensure sate treatment of the NaK. The Contingency Plan will also be implemented if an emergency arises. The NaK has a mineral oil layer which takes approximately seven hours to burn. The NaK itself will burn away in approximately 45 minutes. All wastes and equipment are removed from the treatment area once the burn is complete. 


\section{Building 9201-t, Container Storake Area}

Building 9201-t is located in Emergency Zone 0. on First Street. (jamewell boxes are iocated within the 9201.4 building and are connected to the existung plant (iamewell Fire tlarm System and the Plant Monitoring System. Two-way radios are used. and a telephone is available on the first tloor in the southwest corner of the building tor communication with the PSS office if emergency assistance is needed.

This unit is located within the exclusion area of the Y-12 Plant and is used to store mercury contaminated solids such as soil or insulation in containers. The solids may also be contaminated with uranium. Building 9201.4 provides container storage for 55 - gallon drums of hazardous and mixed waste (contaminated with uranium) resulting from remedial actions .nd demolitions.

\section{Building 9212 Cuntainer Storage Area}

Building 9212 Container Storage Area is located in Emergency Zone 4. in Building 9212. Telephones are available in nearby supervisors' offices. Eye wash/satety showers are available at each location. Two-way radios are also used to communicate with the PSS office if emergency assistance is needed. Gameweil Boxes are located in D.Wing Hall, 15 feet west of column R-7, and on the first tloor. 10 feet east of column R-3. These Gamewell boxes are connected to the existing plant Gamewell Fire Alarm System and Plant Monitoring System.

This area processes organic solutions for recovery of enriched uranium. Process operations within the building generate solid waste contaminated with uranium. The solid waste is burned and the resulting ash is stored in galvanized tin cans. The cans are stored on stainless steel racks with criticality spacing.

\section{Building 9206 Container Storage Area}

Building 9206 Container Storage Area is located in Emergency Zone 4, in Building 9206 and Building 9720-17. For areas located in Building 9206, Gamewell boxes are located near Room 24 and Room 30. Eye wash and safety shower stations are also located in these rooms. For the area located in Building 9720-17, a Gamewell box and a telephone are located in the corridor outside the area. A telephone is available in Room 18 of Building 9206. Two-way radios are also available in these buildings tor communication with the PSS 
office if emergency assistance is needed. Gamewell boxes are connected to the existing plant Gamewell Fire Alarm System and Plant Monitoring System.

Building 9206 is the other building at the Y-12 Plant that processes organic solutions containing enriched uranium for recovery of the uranium. During the recovery process, solid wastes such as gloves, shoe scuffs. lab coats. etc, are generated that are contaminated with uranium. These wastes are burned and the resulting ash stored for future recovery of the uranium contained in the ash. The ash is store in galvanized tin cans, and the cans are stored on stainless steel racks with criticality spacing. Criticality spacing requires the cans to be stored approximately 2 -feet apart.

\section{Uranium Treatment Unit}

Uranium Treatment Unit is located in Emergency Zone 4. near Building 9767-2. Eye wash/safety shower stations are available at this unit. and the nearest Gamewell box is located 75 feet north of the area on the East Dack between Doors 4 and 5. This Gamewell box is connected to the existing plant Gamewell Fire Alarm System and Plant Monitoring System. Two-way radios are used and a phorre is available nearby in Building 9767-2 to communicate with the PSS office if emergency assistance is needed.

The Uranium Treatment Unit is located on the east side of Building 9206, outside and adjacent to the loading dock. The unit consists of two 300-gallon polytanks located within a diked drum storage area that stores up to eighteen 55-gallon drums.

This unit treats organic solutions with less than $400 \mathrm{pp...}$ U-235 until the resulting level is less than 1 ppm U-235.

\section{RCRA and PCB Container Storage Area, Building 9720-58}

Building 9720-58 is located in Emergency Zone 7 on Old Bear Creek Road. Two Gamewell boxes are provided at the east and west side of building 9720-58 and is connected to the existing plant Gamewell Fire Alarm System and the Plant Monitoring System. Telephones and two-way radios are also used by personnel to provide communication with the PSS office if emergency assistance is needed. A portable eyewash system is provided in the operation trailer adjacent to the unit. A safety shower/eye wash system is also provided at Unit OD-9 that is located directly west of building 9720-58. 
Building 9720-58 is utilized as a storage and staging area for PCB contaminated equipment (e.g.. transtormer. capacitors. and electrical switch gear). The area is used to store RCRA hazardous waste and will be used as a staging area tor other Waste. Transportation. Storage, and Disposal (WTSD) areas for waste materials awaiting otf-site shipments. Waste is consolidated at this area until waste analysis and appropriate disposal arrangements can be initiated.

\section{Building 9720-32 Production Waste Storage Unit}

Building 9720-32 will be located in Emergency Zone 6 on South K Road. Three gamewell boxes will be located within Building 9720-32 and will be connected to the existing plant Gamewell Fire Alarm System and the Plant Monitoring System. Telephones and two-way radios will be used by personnel to provide communication with the PED office if emergency assistance is needed. Eye bath/emergency showers will also be provided.

Building 9720-32 will be a unit designed for temporary storage of classitied wastes generated at the Y-12 Plant. The wastes will include materials. fabricated parts. and containers which have been security classified to prevent dissemination of potentially vital information. Stored materials consist of RCRA hazardous. low-level radioactive. and mixed wastes.

\section{Building 9720-12 Classified Container Storage Area}

Building 9720-12 Classified Container Storage Area is located in Emergency Zone 6. The nearest Gamewell box is M631, located in the northwest corner of Building 9720-12. This Gamewell box is connected to the existing plant Gamewell Fire Alarm Svstem and Plant Monitoring System. Portable eye wash and safety shower stations are used. Two-way radios are used to communicate with the PSS office if emergency assistance is needed.

Building $9720-12$ is a storage unit for hazardous and non-hazardous waste and is a long-term storage unit for uranium contaminated solid combustibles generated from Building 9215 process operations. Waste is stored in 55-gallon drums at this building until waste analysis and appropriate recycle techniques can be arranged.

\section{PLANT EMERGENCY DIRECTOR}

The emergency coordinator at the Y-12 Plant is called the Plant Emergency Director (PED). The Y-12 Plant has several Plant Shift Superintendents (PSS) who share the responsibilities of the PED. At least one PSS is on duty 24 hours per day. every day and can be reached 
at (615) 574-7172 (in-plant dial 4-7172) at the Emergency Control Center in Building 9706-2. The alternate Emergency Control Center is located in Building 9213 and phones are transterred if the operations are being conducted at this building. The PSS on duty is responsible for providing continuous plant-wide emergency direction as the PED. If the PED is incapacitated during an emergency, the Fire and Guard Shift Captain on duty is his alternate until another PSS can report to the scene. The PSS, or alternate, has access to names, phone numbers, and addresses of all emergency personnel and will determine who must be contacted to provide emergency activity support.

The names and work numbers of the PSSs are provided below:

$\begin{array}{lcc}\quad \text { Bldg. Location } & \text { Work Phone } \\ \text { J. E. McNabb } & 9706-2 & (615) 574-7172 \\ \text { J. D. Chapman } & 9706-2 & (615) 574-7172 \\ \text { P. C. Norris } & 9706-2 & (615) 574-7172 \\ \text { J. E. Cheek } & 9706-2 . & (615) 574-7172 \\ \text { E. Manis } & 9706-2 & (615) 574-7172 \\ \text { W. M. Bradley } & 9706-2 & (615) 574-7172 \\ \text { L. K. Brooks } & 9706-2 & (615) 574-7172\end{array}$

Responsibilities of the PED

The PED is responsible for the overall direction of emergency efforts as follows:

- Directs emergency service units and local emergency squads.

- At the scene of the emergency, evaluates:

- Radiation and general safety situations as they affect the immediate and adjacent areas

- Need for interrupting utility services such as process water, ventilation, oxygen, natural gas and electricity

- Need for operational charges.

- Considers the need for and arranges for any large-scale alert, evacuation, general alert, invocation of mutual assistance agreements. and procurement of additional emergency personnel or emergency equipment. 
- Keeps Y-12 management and appropriate staff groups informed.

- Determines when the emergency is over. and orders the "all clear" signal.

The office of the PED is responsible for:

- Y-12 Plant-wide emergency planning.

- Updating the Emergency Management Plan.

- Planning for practice exercises.

- Coordinating the organization and training of emergency service units and local emergency organizations.

- Receiving and evaluating emergenciès.

- Activating internal alarm systems to alert/evacuate personnel.

- Coordinate the emergency response team; determine if outside assistance is required.

- Reporting incidents to the DOE/OR in accordance with DOE Order 5000.3A "Occurrence and Processing of Operations Information."

\section{IMPLEMENTATION}

The decision to implement this Contingency Plan. as part of the Emergency Management Plan. depends upon whether an imminent or actual incident could threaten human health or the environment.

The Contingency Plan will be implemented by the PED in the following situations:

- A fire and/or explosion occurs, such that:

- The potential for human injury exists: 
- Toxic fumes that could endanger human health or the environment are released:

- The tire could spread on-site or off-site and possibly ignite other tlammable materials or cause heat-induced explosions:

- The use of water and/or chemical fire suppressants could result in contaminated runoff that could endanger human health or the environment;

- An imminent danger exists that an explosion could ignite other hazardous wastes at the facility and possibly result in the release of toxic materials.

- A spill or release of a hazardous material occurs such that:

The spill could result in release of flammable liquids or vapors, thus causing a fire or gas explosion hazard:

- The spill could cause the release of toxic liquids or fumes that could endanger human health or the environment:

- The spill cannot be contained on, site, resulting in off-site soil contamination and/or ground or surface water pollution that could endanger human health or the environment.

Many ways of discovering a spill or release of chemicals are possible. These include: routine and scheduled inspections of process equipment and material storage areas: unusual or strong chemical odors which may indicate a leak; and instrumentation such as level alarms, automatic sump pumps, and $\mathrm{pH}$ meters which may also reveal chemical spills or system malfunctions.

\section{Identification of Hazardous Wastes}

The PED will immediately identify the character, exact source, amount, and aerial extent of the material involved in the fire or release. The initial identification method will be by visual analysis of the material and location of the release. Plant records, including inventories and process and waste log sheets, are available at the RCRA facilities' operating department offices to aid in estimating the composition and quantity of released material. In the event of a spill, a sample of the spilled material is taken if the material enters a storm drain, there is some question as to the identity of the material, or the material is suspected to contain PCBs. Environmental Monitoring will sample to verify hazardous material identification, to determine boundaries of contaminated areas and contaminant concentrations. and to verify proper cleanup after cleanup activities are completed. 
Information such as storm sewer locations and topographic information is available to support the PED in the process of identifying potential flow/contamination paths and to determine appropriate control actions.

\section{Storage and Treatment of Released Material}

Any hazardous materials that results trom a release, tire, or explosion at the Plant will be contained, removed, and placed in 55-gallon drums (or smaller containers if appropriate). Leaking or damaged containers will be placed in 85-gallon over-pack drums so they can be stored until treatment or disposal arrangements are finalized.

Contaminated absorbent materials, protective clothing, and other disposables used in remediation of the emergency and subsequent decontamination activities will be placed in 55-gallon drums and stored at a RCRA-approved facility pending treatment or disposal. These items will be handled with the same degree of caution as the wastes themselves so that public health and the environment are not further threatened.

Immediately after an emergency, the emergency coordinator will make arrangements for treatment, storage, or disposal of recovered waste, contaminated soil, surtace water, or any other contaminated material. The arrangements will be made with the appropriate RCRA permitted facility.

Emergency and spill response equipment available for clean-up, storage, and treatment are identified in the Y-12 Emergency Management Plan.

\section{Incompatible Waste}

In order to prevent reactions caused by proximity of incompatible substances, wastes which have been spilled or released must be segregated from other wastes or materials which are incompatible. It is a duty of the PED to ensure that wastes which may be incompatible with the released material are not treated, stored. or disposed of in the vicinity of the spill or fire until clean-up procedures are completed.

Incompatible wastes are unlikely to be treated, stored, or located in the affected areas until • cleanup is completed because of the waste segregation practices used at the facility. If possible. no additional wastes will be stored in the atfected area until the cleanup is 
completed. If waste storage there is necessary, wastes will be placed only in those areas where no incompatible wastes are present.

\section{Container Spills and Leakage}

In the event of a hazardous material spill or release, the following general procedures will be used for rapid and safe response and control of the situation. Spills or releases and impending spills or releases discovered during routine inspections will be handled in the same manner as described below for spill and release emergencies. These are general guidelines, and circumstances may dictate some alterations to these procedures.

If an employee discovers a chemical spill or process upset resulting in a hazardous material release. he or she will immediately report it to the area supervisor. The area supervisor or the employee will contact the PSS. When contacted, the PSS will obtain information pertaining to the following:

1. The material spilled or released

2. Location and source of the release or spillage of hazardous material

3. An estimate of quantity released and the rate at which it is being released

4. The direction in which the spill or vapor or smoke release is heading

5. Any injuries involved

6. Fire and/or explosion or possibility of these events

This information will help the PSS to assess the magnitude and potential seriousness of the spill or release. The PSS will contact and deploy the necessary in-plant personnel. If additional assistance is required, the PSS will also contact the Oak Ridge plants that have agreed to provide assistance and the agencies discussed in the Coordination Agreements section of this plan.

The initial response to any emergency will be to protect human health and safety, and then the environment. Identification. containment, treatment, and disposal assessment will be the secondary responses.

Medical assistance tor injured persons will be obtained from the Y-12 Medical Center. 
Cleanup personnel summoned by the PSS will don protective clothing and equipment, as specitied by Industrial Hygiene. Health Physics and Safety Organization. If a tlammable waste is involved. all ignition sources will be removed. and spark and explosion proof equipment and clothing will be used for containment and cleanup activities. If possible, cleanup personnel will try to stop the leak. Special materials, such as tank patch kits, will be kept on hand for temporary repairs. All surrounding materials that could be reactive with the waste materials will be removed. The major components of the waste will be determined.

Absorbent pads. booms, earth. sandbags, sand. and other inert materials will be used to contain, divert, and clean up a spill if it has not been contained by a dike or sump. Sewer plugs are available. if required to isolate a spill. Spills contained within a dike or sump may be pumped back into the appropriate storage tank or drum. if it is structurally sound. All containment and cleanup materials will be placed in drums tor proper disposal. Some items, such as absorbent rags or booms. may have to be cut up. All recovered liquid wastes and contaminated soil that cannot be returned to their original storage tanks or containers will be placed in drums for removal to an approved storage or disposal site.

Most tank and container spills and leaks are contained within the dikes and sumps provided in the tank and container areas. Small spills occurring in a diked area are directed to the sump provided in that area. Immediately atter the spill is detected. the Waste Transportation, Storage, and Disposal Department will be summoned to remove any standing liquids as described above and arrange to have the spilled material taken to a facility approved to handle that particular waste. If necessary, a portable sump pump will be used to pump the diluted waste material into 55-gallon drums. The transter of the spilled material will be pertormed within 24 hours or at the earliest practical time if it is demonstrated that the material cannot be transferred within 24 hours.

If for some reason a chemical spill is not contained within a dike or sump area, an appropriately sized area of isolation will be established around the spill. The size of the area will generally depend on the size of the spill and the materials involved. An area at least 50 feet in all directions will be isolated. For large spills. an area at least 100 feet in all directions will be isolated. When any spill occurs. only those persons involved in overseeing or performing emergency operations will be allowed within the designated hazard area. If 
possible. the area will be roped or otherwise blocked otf. All persons not actively involved in managing the spill will be kept upwind.

If the PED determines that Y.12 and the other DOE plants are unable 10 handle the emergency, then local, state, and Federal authorities will be notitied of the situation. When necessary, evacuation of all potentially affected plant areas will begin as soon as possible.

All emergency equipment used for spill management must be cleaned by the responsible personnel so that it is fit for use prior to resumption of plant operations in the affected areas.

\section{Tank Spills and Leakage}

In the event of a hazardous material spill or release. the procedures described for Container Spills and Leakage apply for tank releases.

\section{EMERGENCY EQUIPMENT}

A listing of the emergency and spill response equipment is provided in the $Y .12$ Emergency Management Plan. In addition, emergency equipment is maintained at the units in this plan for minor releases which include, but is not limited to, absorbent material, fire extinguishers, shovels, shoe scuffs, gloves, eye protection. and protection clothing. The inspection lists and frequency for thie spill response equipment at the units are presented in the $\mathrm{Y} \cdot 12$ Emergency Management Plan.

\section{COORDINATION AGREEMENTS}

The Y-12 Emergency Management Plan details all coordination agreements currently held with local agencies. A copy of this plan has been provided to all mutual aid organizations. Designated emergency coordinators will commit the necessary resources to implement the contingency plan.

\section{EVACUATION PLAN}

All emergencies at Y-12 warrant prompt and deliberate action. Criteria for evacuation have been established. The PED is responsible for determining whether evacuation is necessary. The Y-12 Emergency Management Plan contains details of this criteria. 


\section{REQUIRED REPORTS}

The PED will note in the Plants operating record the time. date. and detals of any incident which required implementation of the Contingency Plan. Internal reports will be tiled as required by DOE and MMES.

Within 15 days after the incident, the Plant will submit a written report on the incident which required implementation of the Contingency Plan to the DOE for review and transmittal to the Commissioner of the TDEC, as required by Tennessee Rule 1200-1.11-.06(6)(g)(10). The report will include:

- Name, address. and telephone number of the owner or operator:

- Name. address, and telephone number of the tacility:

- Date. time, and type of incident (e.g.: fire. explosion);

- Name and quantity of material(s; inyolved:

- The extent of injuries, if any;

- An assessment of actual or potential hazards to public health or the environment, where this is applicable: and

- Estimated quantity and disposition of recovered material that resulted from the incident. 

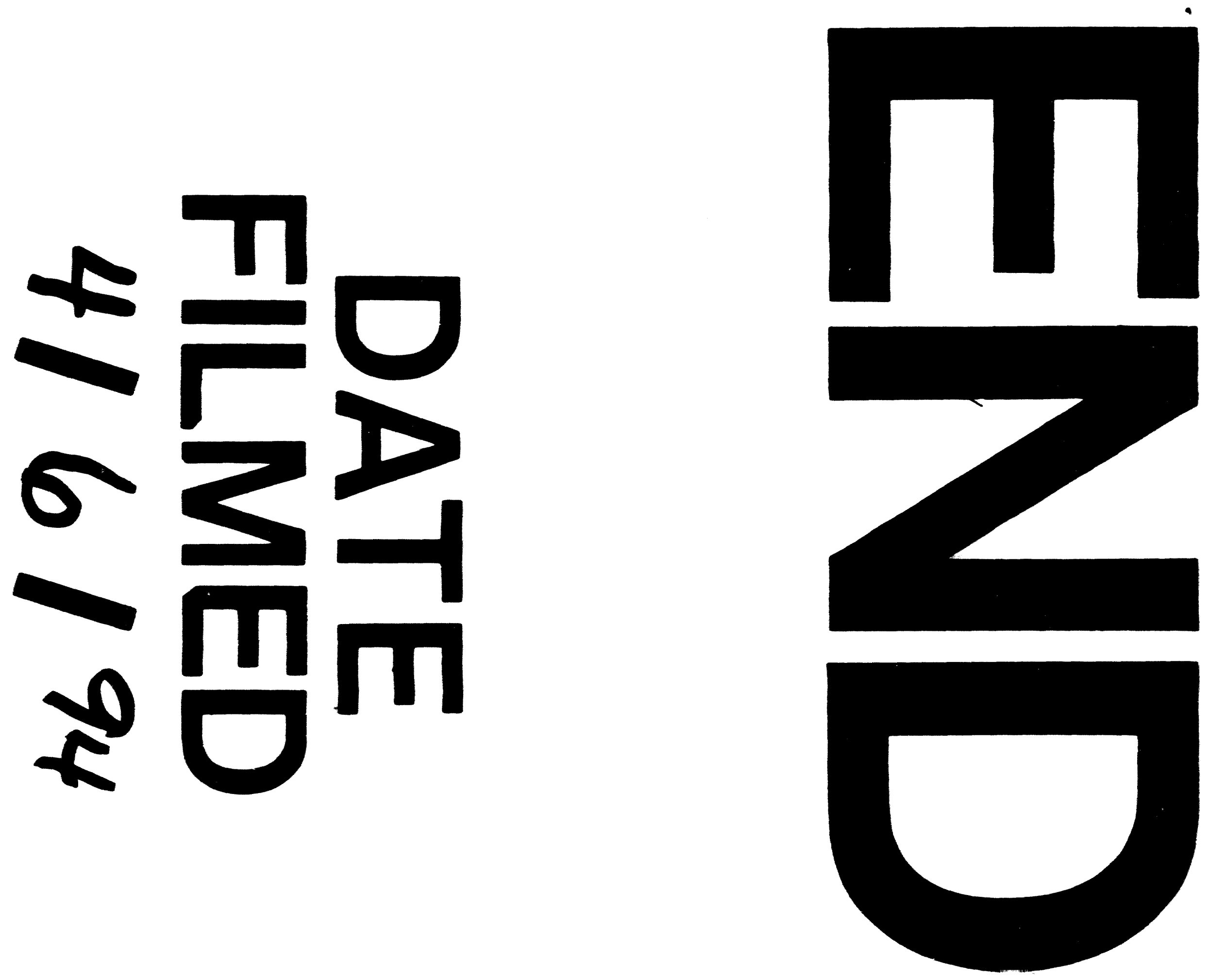
